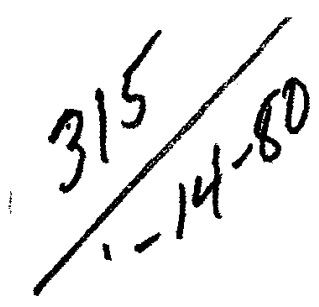

$$
145: 50
$$

MODEL DOCUMENT FOR COOEOFEICHLSON

SOLAR HEATING ANO COOLING OF BUULUNGS

First Draft

March 1979

Work Performed Under Contract No, EM-78-C-01-4281

Council of American Building Officials

Building Officials and Code Administrators International, Incorporated International Conference of Building Officials

National Conference of States on Building Codes and Standards, Incorporated

Southern Building Code Congress International, Incorporated
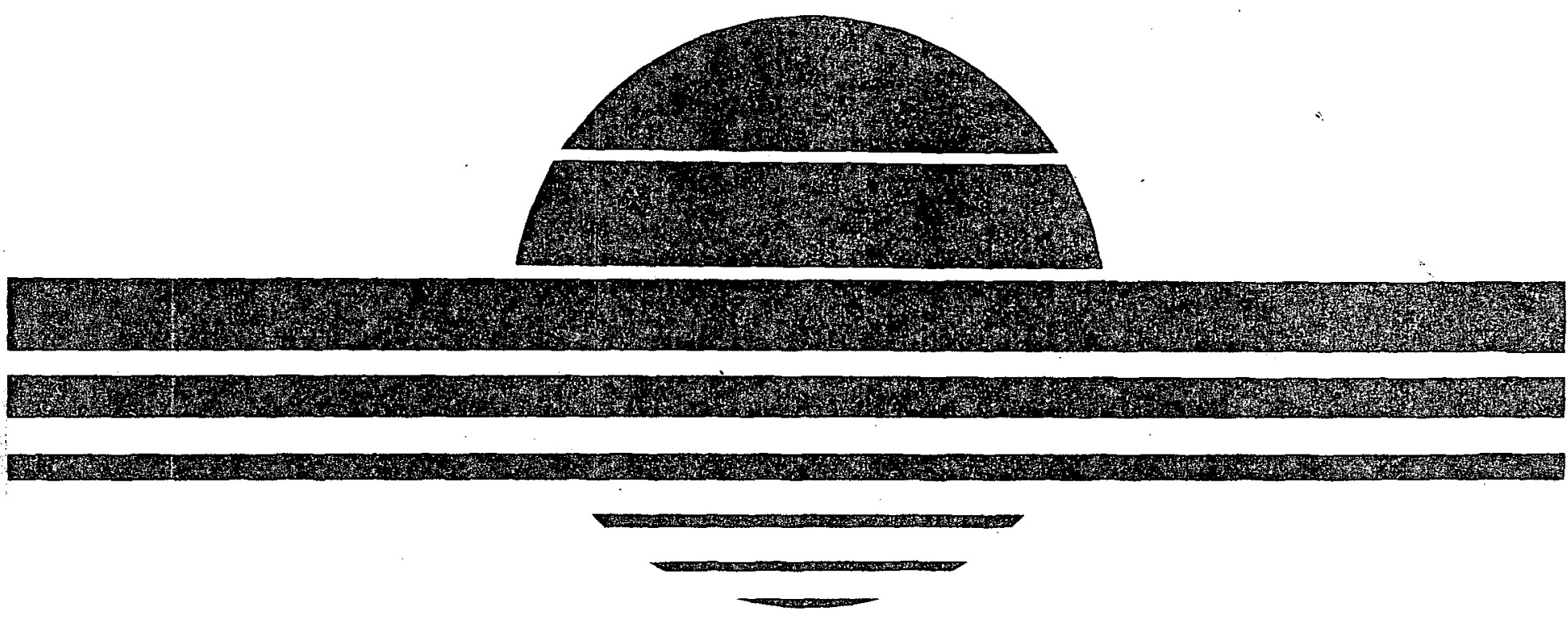

U.S. Department of Energy

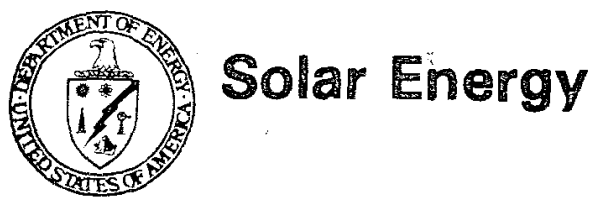




\section{NOTICE}

This report was prepared as an account of work sponsored by the United States Government. Neither the United States nor the United States Department of Energy, nor any of their employees, nor any of their contractors, subcontractors, or their employees, makes any warranty, express or implied, or assumes any legal liability or responsibility for the accuracy, completeness or usefulness of any information, apparatus, product or process disclosed, or represents that its use would not infringe privately owned rights.

This report has been reproduced directly from the best available copy.

Available from the National Technical Information Service, U. S. Department of Commerce, Springfield, Virginia 22161.

Price: Paper Copy $\$ 8.00$

Microfiche $\$ 3.00$ 


\section{DISCLAIMER}

This report was prepared as an account of work sponsored by an agency of the United States Government. Neither the United States Government nor any agency Thereof, nor any of their employees, makes any warranty, express or implied, or assumes any legal liability or responsibility for the accuracy, completeness, or usefulness of any information, apparatus, product, or process disclosed, or represents that its use would not infringe privately owned rights. Reference herein to any specific commercial product, process, or service by trade name, trademark, manufacturer, or otherwise does not necessarily constitute or imply its endorsement, recommendation, or favoring by the United States Government or any agency thereof. The views and opinions of authors expressed herein do not necessarily state or reflect those of the United States Government or any agency thereof. 


\section{DISCLAIMER}

Portions of this document may be illegible in electronic image products. Images are produced from the best available original document. 


\title{
FIRST DRAFT \\ MODEL DOCUMENT FOR CODE OFFICIALS \\ ON SOLAR HEATING AND COOLING OF BUILDINGS .
}

\author{
Prepared for the \\ DEPARTMENT OF ENERGY \\ UNDER CONTRACT NO. EM-78-C-01-4281 \\ Prepared jointly by: \\ COUNCIL OF AMERICAN BUILDING OFFICIALS \\ INTERNATIONAL CONFERENCE OF BUILDING OFFICIALS \\ SOUTHERN BUILDING CODE CONGRESS INTERNATIONAL, INC.
}

BUILDING OFFICIALS AND CODE ADMINISTRATORS INTERNATIONAL, INC.

NATIONAL CONFERENCE OF STATES ON BUILDING CODES AND STANDARDS, INC.

March 1979

This document is

PUBLICLY RELEASABLE

Brmy steel

Authorizing Official

Date: $\quad 7-19-07$ 
The Appendix contains substantial reproductions from the following publications:

THE BASIC MECHANICAL CODE, copyright 1979, published by the Building Officials and Code Administrators International, Inc.

THE I.C.B.O. PLUMBING CODE, copyright 1979, and THE UNIFORM MECHANICAL CODE, copyright 1979, published by the International Conference of Building Officials.

THE STANDARD BUILDING CODE, copyright 1979, published by the Southern Building Code Congress International, Inc.

The above organizations have granted permission to make the reproductions included in this document. 


\section{FORWARD}

The Solar Energy Document is the result of a contract between the Council of American Building Officials (CABO) and the Department of Energy (DOE). The DOE funding support enabled this document to be developed as a useful guide in the code enforcement field using the state of the art now available in the solar energy field.

The primary purpose of this document is to promote the use and further development of solar energy through a systematic categorizing of all the attributes in a solar energy system that may impact on those requirements in the nationally recognized model codes relating to the safeguard of life or limb, health, property and public welfare.

Although solar energy systems are inherently provided for in the model codes it was necessary to develop these guidelines not only as an aid to the designer, consumer, builder and enforcement official but also as an instrument to promote further research in solar energy and the development of meaningful new standards.

The Solar Energy Document was developed using concensus procedures which included balanced representation from the consumers, public interest groups, professionals, builders, 
code enforcement officials, manufacturers, energy suppliers, standards organizations and material suppliers. The initial draft was developed by a project team composed of technical advisors from the Building Officials and Coae Administrators International, the International Conference of Building Officials and the Southern Building Code Congress International. The initial draft was reviewed by balanced technical committees, each having expertise in the four disciplines of building, plumbing, mechanical and electrical. Subsequently regional hearings were held in order to obtain input from all interested parties.

Support is being provided for the document through the development of appropriate educational and innovative systems approval programs. Training courses have been developed under another phase of this joint effort. The course material for the training of those personnel in the use of this document will be made available to state and local governments.

In most regions of the United States solar energy will be used to supplement conventional energy systems used for space heating and cooling, for water heating and for processing purposes. Therefore it will be necessary for the designer, builder and enforcement official to integrate the provisions of this document with existing requirements in the codes relating to 
conventional systems. The more frequently used and applicable code requirements and standards are reproduced from the model codes in order to make the document as self-sustaining as possible.

Administrative provisions have been included to integrate this document with presently adopted codes, so as to allow incorporation into traditional building, plumbing, mechanical and electrical codes. In those areas where model codes are not used it is recommended that the requirements, references and standards herein be adopted to regulate all solar energy systems. 


\section{TABLE OF CONTENTS}

Page No.

Copyright i i

Forward i $i \mathrm{i}$

$\begin{array}{lr}\text { SECTION A - ADMINISTRATION AND ENFORCEMENT } & 1 \\ \text { A-101.0 Scope and General Requirements } & 1 \\ \text { A-102.0 Maintenance and Identification } & 2 \\ \text { A-103.0 Alternate Materials and Methods } & 3 \\ \text { of Construction } & 4 \\ \text { A-104.0 Plans, Permits and Inspections } & 5 \\ \text { A-105.0 Validity } & 6 \\ \text { A-106.0 Violations and Abandonment } & 7 \\ \text { SECTI0N D - DEFINITIONS } & 7 \\ \text { D-101.0 General } & 8 \\ \text { D-102.0 Definitions } & 14 \\ \text { SECTI0N B - BuILING } & 14 \\ \text { B-101.0 General } & 14 \\ \text { B-102.0 Access, Location and Clearances } & 16 \\ \text { B-103.0 Material - Test and Specifications } & 16 \\ \text { B-104.0 Collectors } & 18 \\ \text { B-105.0 Distribution Systems } & 19 \\ \text { B-106.0 Storage Systems } & \end{array}$




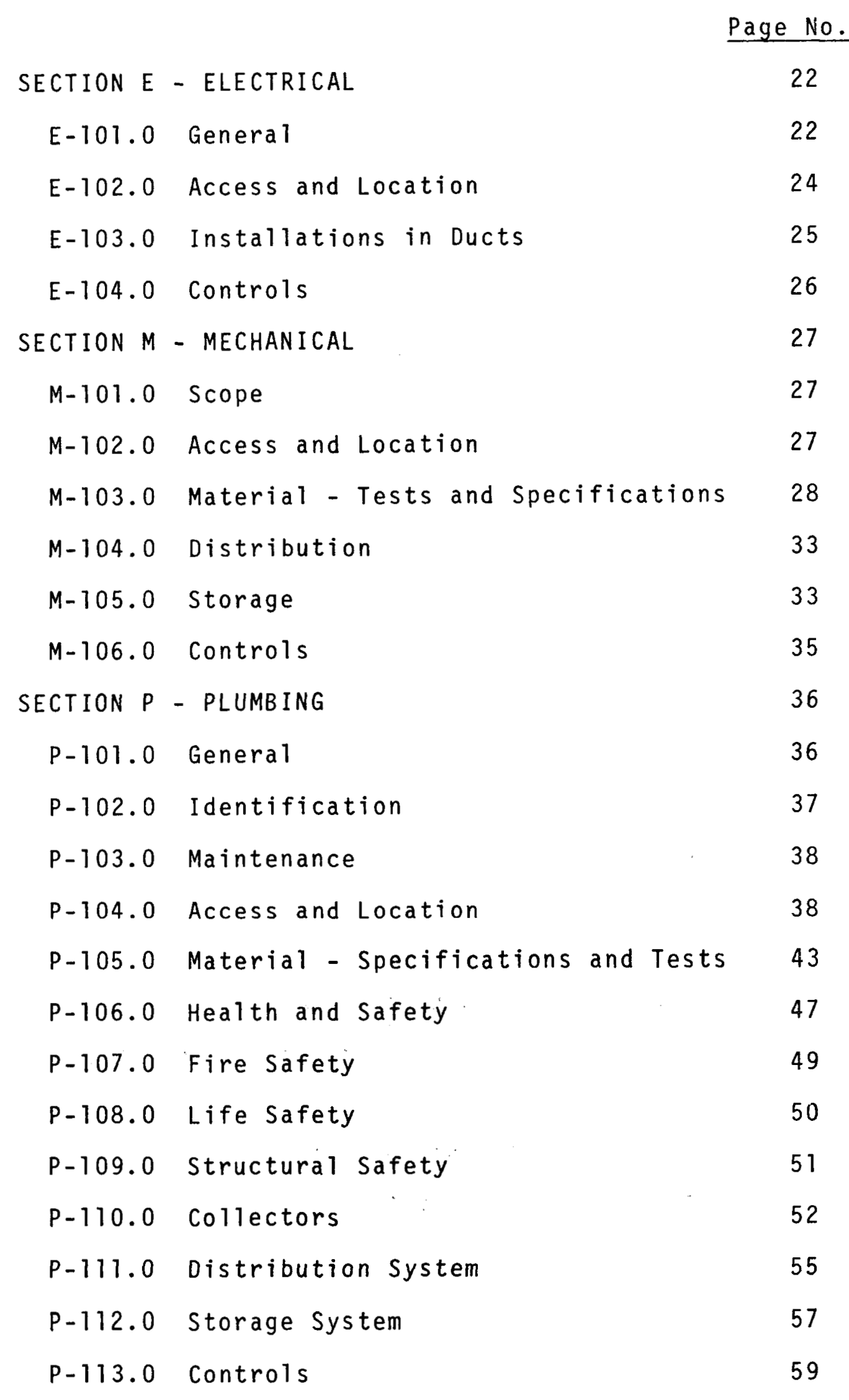


Page No.

$\begin{array}{lc}\text { REFERENCE SOLAR STANDARDS } & \\ \text { Building Section } & \text { RS-B.1 } \\ \text { Electrical Section } & \text { RS-E.1 } \\ \text { Mechanical Section } & \text { RS-M-1 } \\ \text { Plumbing Section } & \text { RS-P.1 } \\ \text { APPENDIX } & \\ \text { Definition Section } & D-1.1 \\ \text { Building Section } & B-1.1 \\ \text { Mechanical Section } & M-1.1 \\ \text { Plumbing Section } & P-1.1 \\ \text { Glossary } & G-1.1\end{array}$




\author{
SECTION A \\ ADMINISTRATION AND ENFORCEMENT
}

\title{
A-101.0 Scope and General Requirements
}

A-101.1 Titre

This document shall be known as the Solar Energy Document, may be cited as such, and will be referred to herein as "document".

\section{A-101.2 Purpose}

The purpose of this document is to safeguard life or limb, health, property and public welfare by regulating and controlling the design, construction, installation, materials, location, operation and maintenance of solar energy systems (active and passive) in buildings and appurtenant structures.

\section{A-101.3 Intent}

The provisions of this document shall apply to the erection, installation, alteration, repair, relocation, replacement, removal, addition to, use, or maintenance of solar energy systems used for space heating and cooling, for water heating and for processing purposes in buildings and appurtenant structures.

It is also the intent to include in this document the necessary references wherever these provisions affect or are 
affected by the requirements of other nationally recognized standards or model codes.

Where different provisions specify different materials, methods of construction or other requirements, the most restrictive shall govern.

\section{A-101.4 Existing Buildings}

Solar energy systems may be installed in or on existing buildings or appurtenant structures without having the entire building or structure comply as required for new construction, provided the added solar energy systems and the affected portions of the existing building, mechanical, plumbing and electrical systems comply as required for new construction.

\section{A-101.5 Existing Solar Energy Systems}

Solar energy systems lawfully installed shall be permitted to have their existing use continued provided their use and maintenance is not a hazard to life, health or property.

Systems that are non-conforming or dangerous to life, $1 \mathrm{imb}$, health, property or public welfare shall be abated in accordance with the Building Code or Appendix B.

\section{A-102.0 Maintenance and Identification}

\section{A-102.1 Maintenance}

All solar energy systems, both existing and new, and all parts thereof shall be maintained in a safe and sanitary 
condition. Required devices or safeguards shall be maintained in accordance with the provisions of this document. The owner or his designated agent shall be responsible for the maintenance of these solar energy systems.

Maintenance instructions for components shall be clearly stated on a readily accessible label. Such label may be limited to identifying, by title or publication number, the operation and maintenance manual for that particular model and type of product.

\section{A-102.2 Identification}

Materials and equipment shall bear the manufacturers' label or otherwise be identified in order to determine compliance with this document.

\section{A-103.0 Alternate Materials and}

\section{Methods of Construction}

\section{A-103.1 General}

The provisions of this document are not intended to prevent the use of any solar energy system or component. Such system or component shall be determined by the enforcement agency to be equivalent in strength, durability, fire resistance and safety to the solar energy systems permitted herein. Substantiating data shall be submitted by the applicant as required by the enforcement agency. 


\section{A-104.0 Plans, Permits and Inspections}

\section{A-104.1 General}

Plans, permits and inspections shall be provided for solar energy systems in accordance with this document.

\section{A-104.2 Plans}

With each application for a building permit, and when required by the enforcement agency, plans and specifications shall be submitted. The enforcement agency may require plans, specifications and calculations be prepared by an engineer or architect licensed to practice by the State. The plans and specifications shall show in sufficient detail, all pertinent data and features of the solar energy system in order to determine compliance with this document. The details shall include, but not be limited to, design criteria, details of solar energy components and size and type of apparatus, equipment and systems controls.

\section{A-104.3 Permits}

Solar energy systems shall not be erected, constructed, enlarged, altered, repaired, moved, improved, removed, converted or demolished without first obtaining a permit from the enforcement agency.

\section{A-104.4 Called Inspections}

The owner or his representative shall notify the enforcement agency, orally or in writing, that work covered by 
the permit is ready for inspection. Such notification shall be given not less than twenty-four (24) hours before the work is to be inspected.

\section{A-104.5 Concealed System}

That portion of any solar energy system intended to be concealed by any permanent portion of the building shall not be concealed until tested, inspected and approved by the enforcement agency.

A-104.6 Connections

Solar energy equipment covered by this document shall be inspected and shall not be connected to the building, plumbing, mechanical or electrical systems until authorized by the enforcement agency.

A-104.7 Final Inspection

When the installation of any solar energy system is complete a final installation inspection shall be made.

\section{A-105.0 Va.1idity}

\section{A-105.1 General}

If any part of this document is for any reason held to be unconstitutional or otherwise illegal, such decision shall not effect the validity of the remaining portions of this document. 


\section{A-106.0 Violations and Abandonment}

\section{A-106.1 Violations}

Any person, firm, corporation or agent who shall

violate a provision of this document shall be determined guilty in accordance with the Building Code or Appendix B.

\section{A-106.2 Abandonment}

Abandoned solar energy systems or parts thereof shall be disconnected from any remaining systems, drained, plugged and capped in an approved manner. 


\section{SECTION D}

DEFINITIONS

D-101.0 General Requirements and Definitions

\section{D-101.1 General}

For the purpose of this document, certain terms, words, phrases and their derivatives shall be construed as specified in this section. Words used in the singular include the plural and the plural the singular. Words used in the masculine gender include the feminine, and the feminine the masculine.

\section{D-101.2 Terms not Defined}

Where terms are not defined, they shall have their ordinarily accepted meanings or such as the context may imply.

D-101.3 Appendix

When no building, mechanical or plumbing codes have been adopted by the enforcement agency Appendix D (Definitions) shall be a part of this document.

\section{$\underline{0}-101.4 \quad$ Conflicts}

Where conflicts occur between definitions contained herein and other reference standards, these definitions shall apply. 


\section{D-102.1 Definitions}

Absorber - The absorber is that part of the solar collector which receives the incident radiation energy and transforms it into thermal energy. It may possess a surface through which energy is transmitted to the transfer fluid; however, the transfer fluid itself can be the absorber.

Absorber Area - The absorber area is the total heat transfer area from which the absorbed solar irradiation heats the transfer fluid or of the absorber media if both transfer fluid and solid surfaces jointly perform the absorbing function.

Absorber Surface - The surface of the collector plate which absorbs solar energy and transfers it to the collector plate.

Active Solar Energy System - An assembly of collectors thermal storage device, and transfer medium which converts solar energy into thermal energy, and in which energy in addition to solar is used to accomplish the transfer of thermal energy.

\section{Adversely affected - Having been interferred with} in a manner detrimental to function. 
Automatic - Self-acting, operating by its own mechanism when activated by some inpersonal influence.

\section{Auxiliary Energy Systems - Equipment utilizing energy} other than solar both to supplement the output provided by the solar energy system as required by the design, conditions, and to provide energy backup requirements during periods when the solar energy system may be inoperable. (Also called a "backup system").

Backflow - The unintentional reversal of flow in a potable water distribution system which may result in the transport of foreign materials or substances into the other branches of the distribution system.

Backflow Preventor - An approved device or means to prevent backflow.

Building Code - Adopted building code of the jurisdiction.

Collector - A component used for absorbing solar radiation, converting it into useful thermal energy, and transferring the thermal energy to a heat transfer fluid.

Combustible Medium - A gas or liquid which will ignite when heated to temperatures greater than $100^{\circ} \mathrm{F}$ below their flash points under either operating or "no-flow" conditions. 
Component - An individually distinguishable (i.e., collector, pump controls or storage tank) product that forms part of a more complex product (i.e., collector subsystem or complete system).

Corrosive Medium - Liquids which when in contact with living tissue will cause damage to such tissue, or will ignite when in contact with organic matter or other chemicals.

Cover, Collector - The collector cover is the material covering the aperture to provide environmental protection.

Electrical Code - The adopted electrical code of the jurisdiction.

Enforcement Agency - The agency and assigned staff designated by the legislative body, charged with the administration and enforcement of this document.

Gross Collector Area - The maximum projected area of the complete collector module including integral mounting means.

Heat Transfer Medium - A liquid, air or solid used to transport thermal energy. 
Maintenance - Any procedure required on a regular basis to keep equipment operating in accordance with this document.

Manual (Adverb) - Operated by personal intervention.

Mechanical Code - Adopted mechanical code of the jurisdiction.

Non-automatic - Action requiring personal intervention for its control.

Outgassing - The emission of gasses or vapors by materials and components usually during exposure to elevated temperature or reduced pressure.

Passive Solar System - An assembly of building components including collectors, thermal storage devices and transfer medium which converts solar energy in a controlled manner and in which the transfer of heat to space is predominently by natural means.

Plumbing Code - Adopted plumbing code of the jurisdiction.

Significantly impaired - Having been damaged or diminished in functional capacity to an extent greater than that allowed for in design or to an extent which results in production of a hazard. 
Solar Collector - A device designed to absorb incident solar radiation and to transfer the energy to a fluid passing through it.

Solar Energy System - A complete assembly of components, equipment, controls, interconnecting means and terminal elements needed to convert solar energy into thermal energy for space heating or cooling, water heating or process energy. Such solar energy systems may work in combination with auxiliary energy systems when required.

Storage - The solar energy system component which receives thermal energy and retains it for future use.

Toxic - Potentially producing illness or injury, either as an immediately evident effect or as an effect evident after a latent period. Effects may be manifested either as injury to the individual exposed or as birth defects in that individuat's future progeny.

Toxic fluids - Liquids or gases whose effect is toxic. Such substances are classified under the Federal Hazardous Substances Act, Part 191, Chapter I, Title 21.

Toxic mediums - A toxic medium is defined as a medium which is equivalent to or less toxic than a Group 6 gas or vapor as classified by Underwriters Laboratories, Inc. Classification method $^{1}$ for gases and vapors. 
Transport system - That portion of a solar energy system which contains a heat transfer medium and moves energy throughout the system through ducts, pipes or other means.

Ultra-Violet Stability - The ability of materials and components to withstand ultra-violet radiation. 
SECTION B

BUILDING

B-101.0 General

B-101.1 Scope

The provisions of this section shall apply to the construction, installation, alteration, location, maintenance and removal of solar systems and accessories connected to or attached to a building or structure.

\section{B-101.2 Building Code}

The provisions of this section shall be used in conjunction with the Building Code. In the event a Building Code has not been adopted Appendix B becomes part of this section and declared to be part of this document.

B-101.3 Systems and Components Integral with the Building

Passive systems and components of active systems which are an integral part of the building shall comply with this document and all applicable sections of the Building Code or Appendix B Section 101.3.

\section{B-102.0 Access, Location and Clearances}

B-102.1 Location

(a) The location of solar energy components in fire districts, yards, courtyards, and public areas shall conform 
with the Building Code or Appendix B. Section 102 .

(b) Location of solar energy components in areas identified by the Building Code as fire separation areas shall be prohibited.

(c) Solar energy components shall not be located so as to interfere with the normal use or operation of doors, windows or other building components.

(d) Provisions shall be made over pedestrian and vehicular ways to restrain or deflect sliding snow and ice.

\section{$\underline{B-102.2 \quad A c c e s s}$}

Solar energy components shall be accessible for routine maintenance without trespassing on adjoining property or disassembling any major portion of the structure of a building or appurtenance.

\section{B-102.3 Clearances}

(a) Combustible materials adjacent to solar components shall not be exposed to elevated termperatures which may cause ignition. Clearances to combustible materials specified in the collector 1 isting or certification report shall be maintained.

(b) Clearance to combustible materials of non-listed collectors shall be subject to approval of the enforcement agency. 


\section{B-103.0 Material Test and Specification}

\section{$\underline{B-103.1 \quad \text { Tests }}$}

The enforcement agency may require tests or test reports as compliance with this document. Tests, if required, are to be made at the expense of the owner or his agent, by an approved testing laboratory or other approved testing agency. Copies of such test reports or the results of all such tests shall be kept on file in the office of the enforcement agency.

\section{B-103.2 Standards}

All design and construction shall comply with the provision of this section governing quality of materials and manner of construction and shall be of adequate strength and proportions to support all superimposed loads within working stresses prescribed in the Building Code or Appendix B Section 103.2.

\section{$\underline{B-104.0 \quad \text { Collectors }}$}

\section{B-104.1 Fire Safety Requirements}

(a) All fire-resistive requirements are expressed in terms of the number of hours of satisfactory performance in accordance with SS B-6.

(b) Collectors located on buildings shall, when required, comply with the fire resistance requirements of the Building Code or Appendix B Section 104.1. 


\section{B-104.2 Collector Supporting Structure}

(a) The collector and supporting structure shall be designed and constructed to support the following loads:

(1) Dead load of the collector, components and transfer liquids.

(2) Live loads required by the Building code or section 3 of SS-B-7.

(3) Snow loads required by the Building Code or Section 7 of SS-B-7.

(4) Wind loads required by the Building Code or Section 6 of SS-B-7.

(5) Seismic loads required by the Building Code or Section 8 of SS-B-7.

(6) Expansion and contraction loads resulting from temperature changes.

(7) Combination of loads of Section 104.2 in accordance with the Building Code or Section 4 of SS-B-7.

(b) Excavations adjacent to any footings shall meet the requirements of the Building Code or Appendix B - Section $104.3(a)$.

(c) Collectors shall be designed for thermal distortion.

(d) Collector plates shall be designed to resist hail loading in accordance with Appendix B - Section 304.3(b). 
B-104.3 Flashing

Flashing shall be placed around openings and extensions of collector supports through the roof as necessary to provide adequate drainage and prevent the penetration of water.

\title{
B-105.0 Distribution System
}

\author{
B-105.1 Fire Rated Assemblies \\ Penetrations of fire rated assemblies shall conform \\ to the Building Code or Appendix B - Section 105.1.
}

\section{B-105.2 Firestopping}

Firestopping shall meet the requirements of the Building Code or Appendix B - Section 105.2.

\section{B-105.3 Fire Dampers}

Fire dampers shall be installed in duct work in accordance with the Building Code or Appendix B - Section 105.3.

\section{B-105.4 Thermal Insulating Materials}

Insulating materials, including vapor barriers, breather papers and similar coverings shall comply with the requirements of the Building Code or Appendix B - Section 105.4.

\section{B-105.5 Structural Integrity \\ Holes, notches, or cuts made in structural elements to allow the passage of distribution system components shall}


not reduce the structural integrity of a member. Notches on the ends of joists or rafters shall not exceed one-fourth the depth. Holes bored for pipes or cable shall not be within two (2) inches of the top or bottom of the joists or rafters and the diameter of any such hole shall not exceed one-third the depth of the member. Notches for pipes in the top or bottom of joists or rafters shall not exceed one-sixth the depth and shall not be located in the middle third of the span. In addition, other specific requirements shall conform to the Building Code or Standard SS-B-1 through SS-B-5.

\section{B-105.6 Flashing}

Flashing shall be placed around all distribution system openings through the roof as necessary to provide adequate drainage, and prevent the penetration of water.

\section{B-105.7 Protection Against Vermin or Rodents}

Solar distribution systems shall not contribute to the entry or growth of vermin or rodents. Protection from vermin or rodents shall be in accordance with the Building code or Appendix B - Section 105.9.

\section{B-106.0 Storage systems}

\section{B-106.1 Firestopping}

Firestopping for storage systems which are an integral part of the building shall meet the requirements of the Building Code or Appendix B - Section 106.1. 


\section{B-106.2 Supporting Structure}

(a) The storage system and supporting structure shall be designed and constructed to support the following loads:

(1) Dead loads of the tank, components, transfer 1 iquids and storage medium.

(2) Live loads required by the Building Code or Section 3 of SS-B-7.

(3) Seismic loads required by Building Code or section 8 of SS-B-7.

(4) Expansion and contraction loads resulting from temperature change.

(b) Excavations adjacent to any footings shall meet requirements of the Building Code or Appendix B - Section 104.

B-106.3 Insulation

Thermal insulating materials shall conform to the requirements of the Building Code or Appendix B-Section 105.4.

\section{B-107.0 Controls}

B-107.1 Fire Rated Assemblies

Control wiring penetrating fire rated assemblies shall conform to the Building Code or Appendix B-Section 105.1. 
B-107.2 Fire Stopping

Firestopping shall meet the requirements of the Building Code or Appendix B-Section 105.2.

B-107.3 Holes, Notches or Cuts

Holes, notches or cuts made in structural elements sha11 conform to section B-105.5.

B-107.4 Flashing

Flashing shall be placed around openings through the roof as necessary to provide adequate drainage and prevent the penetration of water.

B-107.5 Vermin and Rodents Protection from entry of vermin and rodents shall be in accordance with the Building Code or Appendix BSection 105.4 . 
SECTION E

ELECTRICAL

E-101.0 Genera1

E-101.1 Scope

Electrical materials and equipment and their instal-

lation shall be in accordance with reference standard SSE-1

(National Electrical Code, NFPA 70, ANSI C 1 ).

Those conditions typically encountered in the instal-

lation of solar energy systems are covered in this section.

other methods, materials and subject matter covered in

reference standard SSE-1 are also recognized by this docu-

ment. References in brackets [ ] are to specific Articles

or Sections in reference standard SSE-1.

\section{E-101.2 Prevention of Fire Spread}

Electrical installations shall be so made that the possible spread of fire or products of combustion through fire-rated, fire-resistant or fire-stopped walls, partitions, ceilings and floors; hollow spaces; vertical shafts; and ventilating or air-handling ducts will not be substantially increased, and shall conform to the requirements of Section B-104.1. [Sec. 300-21]

E-101.3 Holes and Notches in Structural Members

Holes and notches in structural members shall be made so as to minimize weakening of the building or structure, and shall be in accordance with section B-105.5 or 
the Building Code. Raceways and cables run through holes or notches shall be protected from physical damage. [Sec. $300-4]$.

E-101.4 Loads

Electrical equipment shall be supplied by branch circuit, feeder, and service equipment and conductors which are adequate for the 10ad. No existing branch circuit, feeder, or service shall be overloaded. [Art. 210, 215, $220,230,240,424,430,440]$.

E-101.5 Overcurrent Protection

Conductors and equipment shall be protected against overcurrent as required by reference standard SSE-1, Articles 240,430 and 440 .

E-101.6 Grounding

All exposed noncurrent-carrying metal parts of electrical solar energy system equipment likely to become energized shall be grounded in accordance with the requirements of reference standard SSE-1, Article 250.

\section{E-101.7 Electrical Connections}

Terminals and splicing devices shall be suitable

for the size and number of conductors, and the conductor metal (copper, aluminum, or copper-clad aluminum). [Sec. 110-14] 
E-101.8 Identification of Disconnecting Means

Each disconnecting means required by this Document for motors and appliances, and each service, feeder, or branch circuit at the point where it originates shall be legibly marked to indicate its purpose unless located and arranged so the purpose is evident. The marking shall be of sufficient durability to withstand the environment involved. [Sec. 110-22]

E-101.9 Location with Respect to Adverse Environments Conductors, wiring materials, and equipment shall be inherently suitable or shall be installed so as to be protected when so located as to be affected by:

(a) High temperatures (particularly at collectors and collector piping) and widely varying temperatures. [Sec. 300-7, 310-9, 402-3, 347-3]

(b) Corrosive influences both above and below ground, and including toxic or corrosive heat transfer fluids. [Sec. 300-5, 300-6, 310-8]

(c) Damp and wet locations. [Sec. 300-6(c),346-4]

E-102.0 Access and Location

\section{E-102.1 Access}

Sufficient access and working space shall be provided and maintained about all electric equipment to 
permit ready and safe operation and maintenance of such equipment. [Sec.110-16]

\section{E-103.0 Material Tests and Specifications}

\section{E-103.1 Approved Materials}

Products of a type listed by a nationally recognized electrical testing laboratory shall bear the listing mark of such laboratory. One-of-a-kind equipment, or equipment outside the scope of 1 isting of a nationally recognized electrical testing laboratory may be approved by the enforcement agency. [Sec. 90-4, 90-6, Art. 100 definition of "Listed", Sec. 110-3]

E-103.2 Installation and Use

Listed or labeled equipment shall be used or installed in accordance with any instructions included in the 1 isting or labeling. [Sec. $110-3(b)]$

\section{E-103.3 Marking}

Electrical materials and equipment shall be marked with the manufacturers identification and such electrical ratings as are necessary for proper installation and use. [Sec. $110-21]$

\section{E-103.0 Installations in Ducts}

\section{E-103.1 Wiring Methods}

Only wiring methods approved by the authority 
having jurisdiction for enforcement shall be run within ducts, plenums, and other spaces used for environmental air. Within ducts and plenums no electrical equipment or devices shall be installed except those necessary for their direct action upon, or sensing of, the contained air. [Sec.300-22]

\section{E-103.2 Duct Heaters}

Supplementary electric heaters installed in air ducts shall be installed in accordance with the manufacturers' instructions in a manner so that operation will not create a hazard to persons or property. [Art. 424 Part F]

\section{E-104.0 Controls}

\section{E-104.1 Electrical Controls}

Remote-control, signaling, and power-limited circuits not an integral part of a device or applicance shall be Elass 1, Class 2 , or Class 3 and shall comply with the requirements of reference standard SSE-1, Article 725. 


\section{M-101.0 Scope}

\section{M-101.1 General}

All systems or portions of systems designed to utilize solar energy for building heating or processing with the mechanical movement of air shall comply with the requirements of this section.

Heating, ventilating and air-conditioning equipment and systems which are supplemental to or independent of the solar energy system shall be approved by the enforcement agency.

\section{M-101.2 Mechanical Code}

The provisions of this section shall be used in conjunction with the Mechanical Code. In the event a Mechanical Code has not been adopted, Appendix M-1 becomes part of this section and declared to be part of this document.

\section{M-102.0 Access and Location}

M-102.1 General

All components shall be installed with accessibility for inspection, maintenance, repair or replacement. 


\section{M-102.2 Distribution System}

(a) Equipment in elevator hoistways, elevator machine rooms and machinery spaces shall be located in accordance with Appendix $M-1$ or the Mechanical Code.

(b). The use of uninhabited basements, cellars, crawl spaces, cavity walls, areas above ceilings or attic spaces as supply, make up, exhaust air or return air plenums or ducts shallicomply with the requirements of Appendix $M-1$ or the Mechanical Code.

(c) Outside air intakes and exhaust openings shall be located in accordance with Appendix M-1 or the Mechanical Code.

\section{M-103.0 Material Test and Specifications}

M-103.1 General

The solar energy system components shall not be affected by external environmental factors or operating conditions to an extent that will impair its function. Compliance with the criteria as required herein shall be deemed as meeting this requirement.

\section{M-103.2 Collectors}

(a) Labelling - Manufactured collectors shall be labelled to show the manufacturers' name and address, model number, serial number and collector weight. 
(b) Structural - The collector cover and supportive framing shall be adequate to resist the design snow and wind loads specified for the geographic area and height above grade as determined by $B-100$ of this document.

(c) Thermal Performance

(1) Manufactured Collectors - Data sheets shall be provided showing thermal performance using the method of testing described in SS-M-1 (ASHRAE 93-77) after subjection to the Exposure Test described in Appendix $M-3$.

(2) Site Built Collectors - Data shall be provided showing the average yearly contribution of solar energy collected.

*(d) Durability

(1) Cover Plates

Documentation shall be provided that the cover plate(s) is resistant to degradation by UV radiation for the design life by the manufacturer.

In lieu of other documentation, the transmittance of the cover plate(s) as measured by SS-M-2 shall not change beyond that stated by the manufacturer after exposure using any one of the three aging procedures described in Appendix M-2. The computation of solar transmittance based on the spectrophotometric method 
in SS-M-2 (ASTM E-424) shall be standardized on air mass 2 .

For collectors with multiple covers, the tests below shall be performed with the cover plates in their design configuration.

(2) Absorber Plates

Organic absorber plates shall be resistant to UV radiation for the design life by the manufacturer stated.

In lieu of other documentation, subjection to the Exposure Test described in Appendix $M-3$ without softening, cracking, embrittlement or fading shall be deemed as meeting the intent of this criteria.

(3) Absorbtive Surfaces

Ultraviolet Stability

Documentation shall be provided that the absorbtive coating is resistant to UV radiation for the design life claimed by the manufacturer.

In $1 \mathrm{jeu}$ of other documentation the absorbtive coatings shall not exhibit checking, cracking, blistering or flaking after testing using any one of the three aging procedures described in Appendix $\mathrm{M}-2$.

\section{Moisture Stability}

Documentation shall be provided that the absorbtive coating is not affected by moisture 
with which it comes in contact beyond the design 1 ife claimed by the manufacturer.

In lieu of other documentation, the absorbtive coating shall not exhibit checking, cracking, blistering or flaking after testing for 30 days according to SS-M-3 (ASTM D 2247-68).

(4) Reflective Surfaces Ultraviolet Stability

Documentation shall. be provided that the reflectance properties of the surfaces are resistant to UV radiation for the design life claimed hy the manufacturer.

In lieu of other documentation, the reflectance, as measured for air mass 2 by SS-M-2, method $A$, shall not decrease by more than $10 \%$ after exposure using any one of the three aging procedures described in Appendix M-2.

*The Department of Energy has indicated that a standard is being developed relating to durability of collectors and thermal performance stability. If this standard is developed prior to the publication of this document, it is hoped that these requirements can be deleted and reference made to the test standard.

**(e) Fire Performance - The collector components which are exposed to the air passage shall be non-combustible or Class I material. 
EXCEPTION: When approved smoke detectors are installed in the duct system from the collector designed to stop all air flow through the collector when actuated, plastic collector cover plates may be used when meeting the requirements of Section B of this document.

All insulating materials and adhesives shall have a smoke developed rating not exceeding 50 with a flame spread rating not exceeding 25 .

In addition, insulating materials shall not flame, smolder, glow, or smoke when tested in accordance with SS-M-4.

Outlet air temperatures shall be limited to $200^{\circ} \mathrm{F}$ maximum.

** Underwriters Laboratories is currently developing a standard relating to the fire performance of solar collectors. If this standard is available prior to publication of this document, this requirement could be replaced. with a reference to such standard.

M-103.3 Distribution

The materials used for air distribution such as ducts, plenum, duct linings, duct coverings and flexible duct connectors and material shall conform to the requirements of Appendix $M-1$ or the Mechanical Code of the jurisdiction. 


\section{M-104.0 Distribution}

\section{M-104.1 General}

The air distribution system shall be installed in accordance with the requirements of this section.

\section{M-104.2 Fans and B1owers}

All fans and blowers shall bear the seal of a nationally recognized testing and inspection agency.

\section{M-104.3 Installation of Ducts}

The installation of ducts shall meet the requirements specified in Appendix M-1 or the Mechanical Code.

M-104.4 Fire Dampers

Fire dampers shall be installed in the system locations specified in Appendix M-1 or the Mechanical Code of the jurisdiction.

\section{M-105.0 Storage}

\section{M-105.1 Tank and Storage Materials}

Thermal storage tank materials, including any interior protective coatings and the heat storage medium used shall not impart toxic elements to air distributed to areas of human occupancy. 
M-105.2 Rocks and Pebbles

Rocks or pebbles used as sensible heat storage shall be certified by the supplier as being washed and free of loose sand and organic material prior to placement in the rock storage bin.

Sensible heat storage bins using pebbles, rock or other duct producing mediums shall be filtered at the air outlet.

\section{M-105.3 Combustible Materials}

Combustible materials enclosing phase change materials or otherwise used in latent heat storage systems shall have a flame spread rating not exceeding 25 and a smoke developed rating not exceeding 50 .

As an alternate to this requirement, the storage system materials shall be enclosed in a 1 hour fire resistance rated enclosure in one and two family dwellings and 2 hour fire resistance enclosure in all other occupancies. All openings shall be protected with fire dampers. In addition smoke detectors shall be installed which are designed to stop the air flow through the storage device when activated. Minimum sensitivity of approyed smoke devices shall be set to operate when smoke reduces the intensity of a (1) foot long beam of white 1 ight by four (4) percent or the equivalent.

\section{M-105.4 Heat Loss}

Data shall be submitted showing that the rate of heat loss of the stored energy over a 12 hour period will not exceed 5 percent at design operating temperature. 
Test reports based upon SS-M-5 (ASHRAE 94-77) shal1 also be acceptable.

M-105.5 Waterproofing

Where storage units are located outside or underground, an approved waterproofing material shall be installed.

M-106.0 Controls

M-106.1 Automatic Control

Automatic control of the air circulation between the collector and storage or load shall be used to limit operations to conditions when useful energy can be collected. 


\author{
SECTION P \\ PLUMBING (LIQUID SYSTEMS)
}

\title{
P-101.0 General
}

p-101.1 Scope

All systems or portions of systems using liquid movement or a boiling liquid as a means to utilize solar energy for cooling or heating, for water heating or for processing purposes shall comply with the requirements of this Section.

\section{P-101.2 Plumbing Code}

The provisions of this section shall be used in conjunction with the Plumbing Code. In the event a Plumbing Code has not been adopted the Appendix becomes part of this section and is declared to be part of this document.

\section{P-101.3 Interconnections}

The interconnections of the auxiliary energy plumbing system and components to the solar energy system and components shall be made in a manner which will not result in temperatures or pressures in the auxiliary system exceeding the allowable operating temperatures and pressures of the auxiliary system and shall not bypass the safety devices of the auxiliary system. 


\section{P.102.0 Identification}

\section{P-102.1 General}

All materials and equipment shall be identified by the manufacturers' label in accordance with Section A-102.2 or otherwise be clearly identified to show compliance with this document.

P-102.2 Labeling

Solar energy plumbing components shall be labeled with the following information:

(a) Piping, fittings and valves

1. Company name or registered trademark of the manufacturer.

2. All markings required by the approved standard.

b) Other components (containing liquids or their vapors)

1. Manufacturer's name and address, model number, serial number, and component weight in the drained condition.

2. A11 markings required by the approved standard and. where applicable, the component performance.

3. The name and address or registered trademark of the agency responsible for determining compliance with the applicable approved standards. 


\section{P-102.3 System Labe1ing}

Solar energy plumbing systems and components shall be labeled so as to indicate the type of transfer medium, the direction of flow and the maximum pressure and temperature for the system.

\section{P-103.0 Maintenance}

P-103.1 General

Operation and maintenance instructions shall be provided in accordance with Section A-102.1.

\section{P-104.0 Access and Location}

P-104.1 General

Solar Energy system components other than piping shall be accessible in accordance with section B-102.2 for service and maintenance.

P-104.2 Controls

Solar plumbing system control valves, crossconnection control devices and similar devices shall be readily accessible for service and maintenance.

P-104.3 Attic Equipment

Every attic or furred space in which solar energy equipment is installed shall be accessible by an opening and 
passageway not less than 30 inches by 30 inches continuous from the opening to the equipment and its controls. Where the passageway is less than 5 feet in height, the opening to the passageway shall be located not more than 20 feet from the equipment measured along the center line of such passageway. Every passageway shall be unobstructed and shall have solid continuous flooring not less than 24 inches wide from the entrance opening to the equipment.

A permanent electric light outlet and lighting fixture, controlled by a switch located at the required passageway opening, shall be provided at, or near, the equipment.

\section{P-104.4 Under-F1oor Equipment}

Solar energy equipment other than non-pressurized storage tanks installed in the under-floor crawl space area of any building shall comply with the following requirements:

1. An access opening and passageway not less than 30 inches by 30 inches in height and width shall be provided to the working space in front of the equipment. Where the passageway is less than 5 feet in height, the distance from the passageway access to the equipment shall not exceed 20 feet.

2. Equipment supported on the ground shall rest on a concrete or masonry slab at an elevation such that the equipment will not be subject to ground or surface water. 
3. The lowest portion of any equipment suspended from the building shall have a clearance such that the equipment shall not be subject to ground or surface water. Whenever it is necessary to excavate to install any such equipment, the excavation shall extend to a depth of 6 inches below the equipment and 12 inches on all sides of the equipment, except the control side, which shall, have a clearance of 30 inches.

Whenever the excavation for either the equipment space or for the passageway exceeds 12 inches in depth, the walls of such excavation shall be lined with waterproof concrete or masonry extending to a height of 4 inches above the adjoining ground level.

In flood plane areas wherever there is a possibility that water may overflow the 4-inch curb, the entire crawl space grade or height shall be such that a 12 inch clearance will exist between the bottom of the equipment and the ground.

4. A permanent electric light outlet and lighting fixture, controlled by a switch located at the required passageway opening, shall be provided at, or near, the equipment. 


\section{P-104.5 Exterior Equipment}

(a) General. Installation on roofs or exterior walls of buildings shall comply with the requirements for roof and wall structures as specified in the Building Code, and the equipment shall be listed or approved for such use.

(b) Weather Protection. Unless listed or designed for outside installation, equipment located on the roof of a building shall be in a penthouse complying with the requirements of the Building Code, for roof structures, or shall be completely enclosed in a weatherproof housing. This housing when constructed of metal shall be of galvanized steel or aluminum not less than No. 24 U. S. Standard gage supported on a substantial metal frame. The housing shall be not larger than necessary to properly cover and provide a minimum 6-inch clearance around the equipment enclosed therein, including all controls and draft hoods.

(c) Platform. Equipment, other than collectors, located on a roof of a building shall be installed on a substantial level platform. Whenever the roof has a slope greater than 4 -inches measured vertically to 12 inches measured horizontally, a level working platform not less than 30 inches in depth shall be provided in front of and at the sides of the equipment. All sides of any working platform facing any portion of the roof edge below the platform shall be protected by a substantial railing 42 inches in height with vertical rails not more than 21 inches apart, except that parapets at least 24 inches in height may be utilized in lieu of rails or guards. 
(d) Catwalk. A catwalk not less than 16 inches in width and provided with substantial cleats spaced not more than 16 inches apart shall be provided from the roof access to every required working platform at the equipment.

EXCEPTION: This requirement shall not apply if the slope of the roof is not more than 4 inches measured vertically to 12 inches measured horizonta11y.

(e) Roof Scuttle Access. Working platforms, railings and catwalks required by (c) and (d) above may be omitted when access to the equipment is through a required roof scuttle and all of the following provisions are met:

1. The required scuttle is located immediately adjacent to the control side of the equipment unit.

2. All controls, filters, burners, fans and motors are accessible for service and repair within 2 feetof the edge of the equipment platform on the scuttle side.

3. The equipment platform is not more than 20 inches above the high side of the scuttle opening.

4. A substantial working platform not less than 30 inches by 30 inches shall be provided directly below the scuttle at a point not less than 30 inches or more than 32 inches below the high side of the scuttle opening.

5. Scuttles located on other than the roof incline side of the equipment unit shall have their lids 
or trap doors hinged on the low side of the scuttle. Such lids or trap doors shall be equipped with means to insure an opening radius of not less than 90 degrees nor more than 100 degrees from the closed position. Scuttle lids or trap doors and hardware, when open, shall be capable of withstanding a 300-pound lateral stress from the roof incline side.

6. Access to such scuttlez shall comply with the requirements of section $P-104.0$.

(f) Access. Equipment installed in or on an exterior wall of a building, which is so designed that the controls are serviceable only from outside the building, shall be readily accessible.

Equipment located on the roof of any building shall be readily accessible.

EXCEPTION: 1. Permanent exterior 1adders providing roof access need not extend closer than 8 feet to the finish grade.

2. For equipment on a single-story portion of a Merchantile or Residential Occupancy, a portable ladder may be used.

\section{P-105.0 Material Specifications and Tests}

\section{P-105.1 General}

Materials used in solar energy systems shall conform to the applicable standards set forth in the Plumbing code or 
the Appendix.

P-105.2 Environment

Materials which may be adversely affected by environmental factors for both filled and drained conditions shall be protected in an approved manner.

\section{P-105.3 Temperature and Pressure}

Materials which may be adversely affected when exposed to the temperatures and pressures developed in the solar energy system shall be protected in an approved manner.

\section{P-105.4 Compatibility}

Materials. which are in contact, including heat transfer fluids, shall be chemically compatible. Provisions shall be made to allow for differences in the expansion and contraction of joined materials due to temperature fluctuations.

\section{P-105.5 Abrasives}

Materials which may be adversely affected by abrasive wear caused by the flow of heat transfer fluids, cleaning, or by natural factors such as wind-blown sand shall be protected in an approved manner.

\section{P-105.6 Soil Corrosion}

Materials installed in soil shall not be adversely affected or shall be protected by a protective coating. The 
coating and its application shall conform to applicable standards.

\section{P-105.7 U1traviolet Stability}

Materials that are normally exposed to UV radiation while in service shall not be adversely affected by such radiation. Documentation shall be provided demonstrating that such materials are capable of withstanding exposure to sunlight when tested in accordance with Standard SS-M-2.

P-105.8 Joints and Connections Between Dissimilar Metals Dissimilar metals shall either be electrically isolated from each other or documentation shall be provided to demonstrate that the joints and connections are sufficiently compatible to prevent corrosion.

\section{P-105.9 Metals}

Metals used in contact with heat transfer liquids shall conform to the requirements in Appendix $P-4$.

\section{P-105.10 Nonmetallic Materials}

Nonmetallic materials in direct contact with the heat transfer liquids shall be tested in accordance with Standard SS-P-1 and found to be satisfactory for the intended use. 
P-105.11 Valves

Valves in contact with heat transfer liquids

shall be compatible with the heat transfer liquid as required in Appendix P-4 and Standard SS-P-2.

P-105.12 Chemical Decomposition

Products expelled from materials under in use conditions shall not adversely affect the operation of the system.

$\underline{p-105.13 \text { Sealants }}$

Sealants in pressurized systems shall be tested for the maximum service pressure.

$\underline{P-105.14 \quad \text { Leakage }}$

Leakage from assemblies or subassemblies which contain heat transfer fluids shall be provided for and shall not adversely affect equipment, structural components or persons which may come in contact with the leaking heat transfer fluid or create a safety hazard.

\section{P-105.15 Pipe Hangers}

Pipe hangers shall not damage those materials they are in contact with and shall allow for movement of the supported systems caused by thermal expansion and contraction. 
P-105.16 Pipe Insulation

Solar energy piping systems shall be insulated in accordance with Table $P-1$.

TABLE P-1

Minimum $P$ ipe Insulation

Thermal Resistance ( $R$ Value)

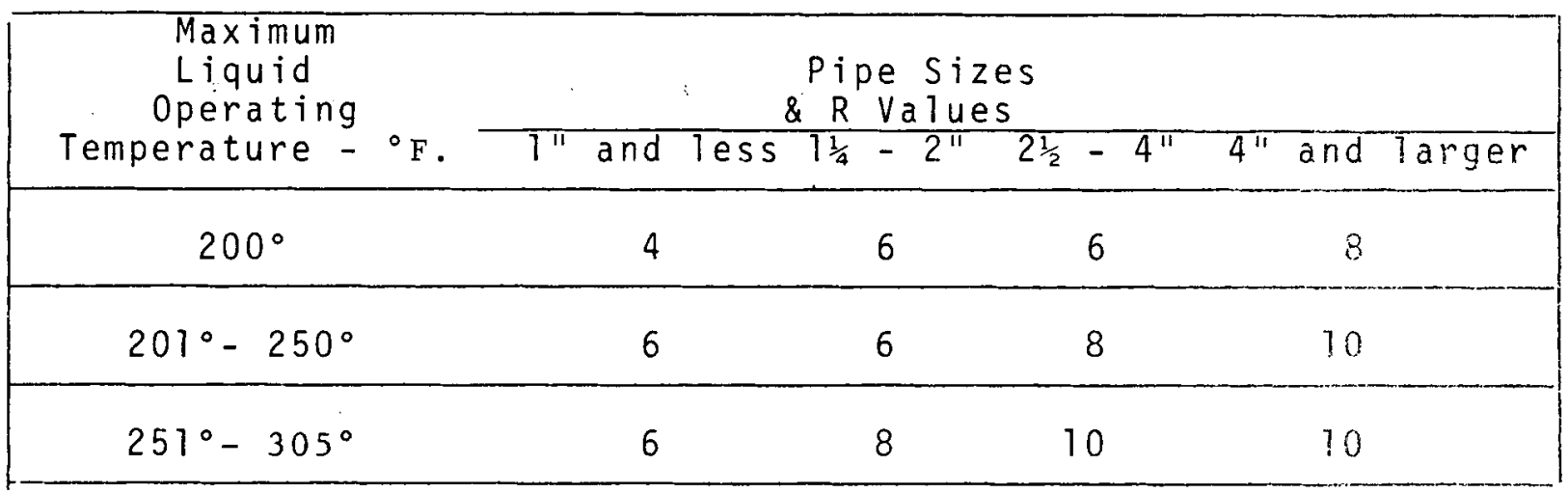

\section{P-106.0 Health and Safety}

\section{P-106.1 Toxicity}

Materials shall not introduce toxic substances, im. purities or bacteria into air circulation systems.

\section{P-106.2 Fungi Protection}

Materials and processes used in solar energy systems

shall not promote the growth of fungi, mold, or mildew when tested in accordance with standard SS-P-3.

\section{P-106.3 Rodent Protection}

Solar energy systems shall not contribute to the entry of vermin or rodents as set forth in section B-105.7. 


\section{P-106.4 Potable Water Supply Protection}

The connection of the solar energy system to the potable water supply system shall conform to the crossconnection requirements of the plumbing code or Appendix P-1 of this document.

\section{P-106.5 Drainage}

Solar energy systems shall provide for the drainage of heat transfer fluids in accordance with the indirect and special waste provisions of the plumbing code or Appendix P-2.

\section{P-106.6 Hazardous Material Drainage}

Drains in solar plumbing systems where hightemperature or high-pressure fluids are discharged shall have a warning label describing the hazardous properties of the fluid, instructions concerning the safe handling of the fluid, and emergency first-aid procedures. Valves regulating suchdischarge shall not be accessible to unauthorized personnel.

\section{P-106.7 Heat Transfer Medium}

Heat transfer mediums which are classified as refrigerants shall conform to the requirements of the mechanical code or Appendix P-5 for Group I refrigerants.

\section{P-106.8 Hazardous Heat Transfer Mediums}

Heat transfer mediums which are toxic, combustible, or corrosive as defined in this document shall not be used in 
solar energy systems except when approved by the authority having jurisdiction.

P-106.9 Draining and Filling of systems

Solar energy systems shall be capable of being vented and filled without air entrapment.

P-106.10 Protection from Heated Components

Solar energy systems and components which are subject to contact by unauthorized personnel and which are maintained at elevated temperatures at or above $140^{\circ} \mathrm{F}$, shall be protected in an approved manner to prevent contact.

\section{$\underline{\text { P-107.0 Fire Safety }}$}

P-107.1 Fire Resistance

Solar Energy systems shall be fire protected in accordance with Section B-104.0.

\section{P-107.2 Penetration}

Penetrations of fire-resistive assemblies by solar energy system components shail conform to the requirements of Section B-105.1.

\section{P-107.3 Firestopping}

Firestopping shall conform to the requirements of Section B-105.2. 


\section{P-107.4 Flame Spread}

The flame spread classification of insulation materials shall not exceed 200 when tested in accordance with $S S-B-8$.

\section{P-107.5 Smoke Density}

The smoke density classification of insulation materials shall not exceed 50 when tested in accordance with SS $-B-8$.

\section{P-107.6 Combustible Material Clearance}

Clearance shall be maintained between solar energy components operating at elevated temperatures and adjoining combustible materials. Clearance shall be in accordance with the equipment listing.

\section{P-108.0 Life Safety}

\section{P-108.1 Pressure Relief}

Adequately sized relief devices shall be provided in pressurized solar energy systems and sub-systems which may be isolated by valving. The devices shall be set to relieve the pressure at the lowest maximum design pressure encountered in the system. The devices shall be drained in accordance with Section P-106.5 of this section. 


\section{P-108.2 Vacuum Relief}

The solar energy plumbing system and components shall be protected against possible collapse by design or by provision of vacuum relief valves.

\section{P-108.3 Temperature Relief}

Approved adequately sized and responsive temperature relief devices shall be provided in those parts of the solar energy plumbing system (and components) which may be isolated by valving and which contain components that add energy to the system. Such devices shall be installed with the temperature-sensing element located as close as practical to the hottest point of the above-described section. Additional temperature relief valves shall be installed if required to satisfy all possible modes of operation. The entire system shall be designed to operate at the maximum operating temperature encountered in the system. The temperature relief devices shall be set to relieve at or below this maximum temperature. Temperature relief devices shall drain to locations in accordance with paragraph $P-106.5$ of this section.

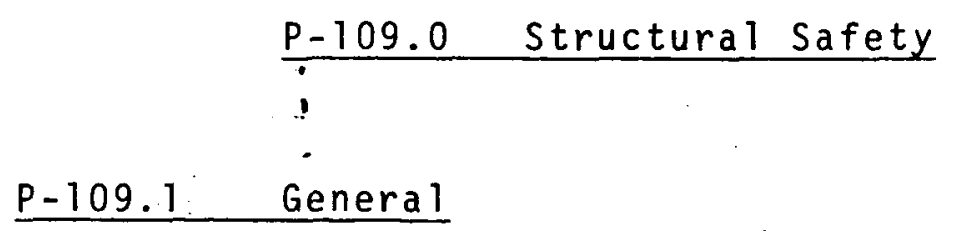

Solar energy systems shall be designed and constructed in accordance with the building, plumbing and mechanical codes or with this document. 


\section{P-109.2 Freeze Protection}

Solar energy systems subject to freezing of the heat transfer fluid shall be protected by draining, circulation of an antifreeze or other approved method.

P-109.3 Thermal Distortion

Solar energy systems shall be designed to accomodate thermal distortion.

\section{P-110.0 Collectors}

\section{P-110.1 Identification}

Solar energy collectors shall be identified in accordance with Section 102.0 and shall be installed in accordance with their listing which shall include the following parameters:
(a) Minimum clearances
(b) Type of heat transfer fluid
(c) Maximum operating temperatures
(d) Maximum operating pressure
(e) Filled collector weight

P-110.2 Material - Specifications and Tests P-110.2(a) Thermal Performance: The thermal performance of the collector shall be determined using the following parameters. 
1. Manufactured collectors.

Data sheets shall be provided showing the thermal performance using the method of testing described in SS-M-1 (ASHRAE 93-77) after subjection to the exposure test described in Appendix M-3.

2. Site Built Collectors. Data prepared by a 1 icensed engineer or architect shall be provided showing the average yearly contribution of solar energy collected.

P-110.2(b) Ultraviolet Stability: Ultraviolet Stability of the collector components shall be determined as follows:

1. Cover plates.

Documentation shall be provided that cover plates are resistant to degradation by UV radiation for the design life stated by the manufacturer. In lieu of other documentation, the transmittance of the cover plate as measured by SS-M-2 shall not change beyond that stated by the manufacturer after exposure using any one of the three aging procedures described in Appendix M-2. The computation of solar transmittance based on the spectrophotometric $\because$ method in SS-M-2 shall be standardized on air mass 2 .

For collectors with multiple covers, the tests in Section P110.2(b) 2 shall be performed with 
the cover plates in their design configuation.

2. Absorber Plates.

Organic absorber plates shall be resistive to

UV Radiation for the design life stated by

the manufacturer.

In lieu of other documentation, subjection to

the Exposure Test described in Appendix $M-3$

without softening, cracking, embrittlement

or fading shall be deemed as meeting the intent

of this criteria.

3. Absorbtive Surfaces.

Documentation shall be provided that

the absorbtive coating is resistant to

UV radiation stated for the design life by

the manufacturer. In lieu of other documentation

the absorbtive coatings shall not exhibit check-

ing, cracking, blistering or flaking after

testing using any one of the three aging pro-

cedures described in Appendix M-2.

4. Reflective Surfaces

Documentation shall be provided that the reflectance properties of the surfaces are resistant to UV radiation for the design

life stated by the manufacturer.

In 1 ieu of other documentation, the reflectance, as measured for air mass 2 by $S S-M-2$, method A, shall not decrease by more than $10 \%$ 


\section{after exposure using any one of the three aging procedures described in Appendix M-2. P-110.2(c) Moisture Stability. Documentation} shall be provided that absorbtive coatings are not affected by moisture with which it comes in contact with beyond the design life stated by the manufacturer. In lieu of other documentation, the absorbtive coating shall not exhibit checking, cracking, blistering or flaking after testing for 30 days in accordance with SS-M-3.

P-110.3 Structural Safety

Solar energy collectors and their supports shall be designed in accordance with Section B-104.2.

\section{P-111.0 Distribution}

\section{P-111.1 Material - Specifications and Tests}

P-111.1(a) Piping. Piping used in solar energy distribution systems shall be installed in accordance with the plumbing code or Appendix P-3. Hangers and supports shall be installed in accordance with the plumbing code or Appendix $P-6$. Piping shall be sized to limit the fluid velocity to recommended levels considering the type of fluid and the piping material.

$$
\text { P.-111.1(b) Valves. Shut-off valves shall be }
$$
gate valves, butterfly valves, or similar valves that open to within 90 percent of full pipe bore. Globe, ball, butterfly or similar valves shall be used for flow control. 
111.1(c) Heat Exchangers. Heat exchangers used in domestic water heating systems shall comply with Standard SS $-\mathrm{P}-4$.

P-111.2 Structural Safety

Solar energy distribution systems and their supports shall be designed in accordance with Section B-104.2. Tanks shall be provided for thermal expansion in the solar energy distribution system.

\section{P-111.3 Testing}

Solar heating systems using liquid heat transfer fluids, not directly connected to the potable water supply, shall be tested for pressures of not less than $1-1 / 2$ times the design pressure for a minimum of 15 minutes. The portion of the system connected to the domestic water system shall be tested in accordance with the plumbing code or Appendix P-7.

\section{P-111.4 System Cleaning}

After completion of piping tests and after all

equipment has been installed, the entire liquid systems shall be thoroughly flushed to remove sediment, dirt, and loose scale, etc. Strainers shall be cleaned or replaced. During the flushing of the system, the collectors shall be disconnected or bypassed to preciude passage of debris through the collectors. Fluids used for leak testing shall be the same as the fluid to be used in the system or such fluids that will be compatible with the fluid to be used, or the 
manufacturers instructions shall be followed.

\section{P-112.0 Storage}

P-112.1 Access and Location

Solar energy storage systems and their equipment

shall be installed in accordance with Sections P-104.3, $P-104.4, P-104.5$ and $B-102.0$.

P-112.2 Material - Specifications and Tests

Solar energy storage systems materials shall conform to the requirement of Section P-105.0.

P-112.3 Health Safety

P-112.3(a) Cleaning. Solar energy storage systems shall be cleaned following installation and piping tests.

p-112.3(b) Covers. A11 openings into tanks except vents shall be tightly covered to prevent entry of unauthorized persons, dirt, and vermin. Vents shall be screened with corrosion-resistant material having not more than 20 openings per linear inch.

\section{P-112.4 Testing}

Pressurized tanks shall be tested in accordance with Section P-111.3. Non-pressurized tanks shall be tested visually for leaks by filling. Fluids used for leak testing shall be the same as the fluid to be used in the system. 
P-112.5 Inlet and outlets

The inlets and outlets piping for thermal storage in solar energy storage systems shall be located in the container so as to prevent thermal "short circuiting" of the fluid flow.

\section{P-112.6 Insulation}

Solar energy storage systems shall be insulated to prevent no more than 4 percent heat loss of the stored energy over a 24 hour period except for systems that are used for space heating only and the container is used to supplement the heating requirement of the conditioned space.

\section{P-112.7 Tank Drainage}

Solar energy storage systems shall be drainable.

Tanks located above grade shall be drained at the lowest point. Underground tanks shall use mechanical means for drainage.

P-112.8 Tank Filling

Solar energy storage systems shall have fluid level indicators and overflows directed away from the building. Make-up water from the potable water system shall be filled in accordance with the plumbing code or Appendix $P-1$ using an air cap. 


\section{P-112.9 Shutoffs}

Shutoff valves shall be provided between the supply system and cold and hot water storage tariks.

\section{P-113.0 Controls}

\section{P-113.1 General}

Solar energy plumbing systems shall be equipped with controls so as to prevent the following conditions from developing:

(a) The addition of energy to the storage media when the temperature of the storage media has reached its maximum design operating temperature.

(b) Undesirable energy loss as a result of thermosiphoning.

(c) Heat transfer fluids in the collector rising above their maximum design operating temperature. The pressure and temperature relief devices required in Section 108 shall not be considered as controls to satisfy this condition.

(d) Heat transfer fluids that are circulated when they exceed their designed operating temperature range.

Provisions of this subsection shall not apply where adequate data is submitted demonstrating that these conditions will not occur due to the design and location of the system. 
REVISED $3-7-79$

P-113.2 Fail Safe

The solar energy control system shall revert to a fail safe mode in the event of a power failure. 
SS - B-1 Concrete.

Building Code Requirements for Reinforced Concrete . . . . . . . . . . ACI 318-76

Bullding Code Requirements for Structural

Plan Concrete

ACI 322

SS - B-2 Masonry.

Building Code Requirements for Masonry . A ANSI A41.1-70

Building Code Requirements for Reinforced

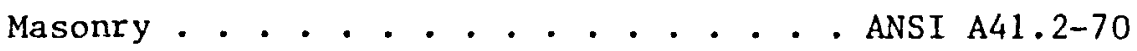

SS - B-3 Aluminum.

Specification for Aluminum Structures,

Aluminum Construction Manual . . . . AA-SAS30-76

SS - B-4 Stee1.

Design of Cold-Formed Steel Structural Members -

Specification for . . . . . . . . AISI-68

Design, Fabrication and Erection of Structural

Steel for Buildings - Specification for . . AISC-S310-69

Supplement No.1 . . . . . . . AISC-S319-70

Supnlement No. 2. . . . . . . . AISC-S320-71

Supplement No. 3 Revised . . . . . AISC-S321-75

$R S-B-1$

Building 
Design of Cold-Formed Stainless

Steel Structural Members - Specification for. . AISI-74

Longspan Steel Joist LJ and LH Serfes, and

Deepspan Steel Joists DLJ and DLH Series -

Standard Specifications for . . . . SJI/AISC-74

Metal Bu1lding Systems Manual . . . . . MBMA-74

Open Web Steel Joists, J-Serles and II-Series-

Standard Specification for ...... SJI/AISC-74

Structural Joints Using ASTM A325 or A490 Bolts -

Specifications for . . . . . . AISC-S314-76

Welding Code, Structural ....... AWS D1.1-75

-Revision No. 1........ AWS D1.1-Rev.1-76

-Revision No. 2........ AWS D1.1-Rev.2-77

SS - B-5 Wood and Wood Products.

Adhesives for Field Gluing Plywood to Wood Framing -

Performance Specifications for ... APA-AFGO1-74

Al1-Weather Wood Foundation System-

Basic Requirements . . . . . . NFoPA-TR7-76

-1977 Supplement . . . . . . . . NFoPA-TR7-77

Code of Suggested Practices - Timber

Construction Standard . . . . . . AITC 106-77

Construction Details - Typical Timber

Construction Standard . . . . . AITC 104-76

Building

$R S-B-2$ 
Heavy Timber Construction - Standard for. . .AITC 108-69 Joists and Rafters.

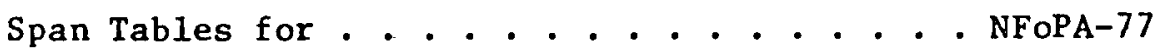
Design Values ............ . . NFoPA-77 National Design Specification for Wood Construction . . . . . . . . . . . . . . . . . . . . . . . . -1977 Supplement (Design Value) ..... . . NFoPA-77 Plywood Commercial/Industrial Construction Guide . . . . . . . . . . . .APA-Y300-76 Plywood Design Specifications . . . . . .APA-Y510-76 Plywood-Lumber Components - Design Specifica-

tions for (includes curved panels, beams, stressed-skin pane1s, sandwich panels, dlaphragm construction and folded plates) . APA-V820-77 Plywood Residential Construction Guide . . . APA-Y405-76 Structural Design Date, Wood ....... NFoPA-70 Structural Design Guide for Hardwood Plywood . . HPMA-HP-SG-72 Structural Glued Laminated Timber Inspection Manual for ........ AITC 200-73 Structural Timber Framing-Standard for the

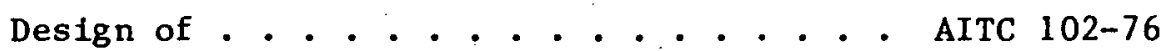
Timber Construction Manual ...... . . AITC-74 Trusses-Design Specifications for Light Metal Plate Connected Wood ........... TPI-74 Wood Handbook ........ USDA Handbook No. 72-74 


$$
\begin{array}{r}
\text { SS - B-6 - Standard Methods of Fire Tests of } \\
\text { Building Construction and Materials }
\end{array}
$$

SS - B-7 - Building Code Requirements for Minimum Loads in Buildings and other Structures

SS - B-8 - Surface Burning Characteristics

$$
\text { of Building Materials }
$$

SS - B-9 - Standard Methods of Fire Tests

of Door Assemblies
ASTM E119

ANSI A58.1

ASTM E-84

ASTM E-152 
March 7, 1979

\section{REFERENCE STANDARDS \\ ELECTRICAL SECTION}

SS-E-1 National Electrical Code...... NFPA 70 
$$
.
$$ 


\section{REFERENCE STANDARDS}

MECHANICAL SECTION

SS-M-1 Thermal Performance of Solar Collectors - Testing . . . . ASHRAE 93-77

SS-M-2 Solar Energy Transmittance and Reflectance....... ASTM E 424-71

SS-M-3 Coated Metal Specimens at 100

Percent Relative Humidity -

Testing........... ASTM D 2247-68

SS-M-4 Hot-Surface Performance of High-

Temperature Thermal Insulation -

Test............ASTM C 411-61

SS-M-5 Thermal Storage Devices Based on

Thermal Performance - Testing . ASHRAE 94-77 
$\vartheta$

$\theta$ 


\section{REFERENCE STANDARDS \\ PLUMBING SECTION}

$\begin{array}{lll}\text { SS-P-1 } & \text { Non-Metallic Materials } & \text { - To be developed } \\ \text { SS-P-2 } & \text { Values } & \text { - To be developed } \\ \text { SS-P-3 } & \text { Fungi Protection } & \text { - To be developed } \\ \text { SS-P-4 Heat Exchangers } & \text { - To be developed }\end{array}$

$R S-P-1$ 
$$
.
$$ 


\section{APPENDIX D}

Accessible - Admitting close approach which may require removal of access panel, door, or similar obstruction.

Accessible, readily - Direct access without the necessity of removing any panel, door, or similar obstruction.

Alley - Any public space or thoroughfare less than 16 feet but not less than 10 feet in width which has been dedicated or deeded to the public for public use.

Area (Building) - Is the maximum horizontally projected area of the building at or above grade, exclusive of court and vent shafts.

Attic - The space between the ceiling beams of the top habitable story and the roof rafters.

Attic Story - Any story situated wholly or partly in the roof, so designated, arranged, or built as to be used for business, storage, or habitation.

Basement - That portion of a building which is partly below and partly above grade, and having at least one-half its height above grade (see "Grade", "Story" and "Cellar").

$$
D-1.1
$$


Building - Any structure used or intended for supporting or sheltering any use or occupancy.

Cellar - That portion of a building which is partly or completely below grade and having at least one-half its height below grade.

Combustible Building Material - One not meeting the standards for a noncombustible building material as defined herein.

Court - A space, open and unobstructed to the sky, located at or above grade level on a lot and bounded on three or more sides by walls of a building.

Fire-Resistance Rating - The time in hours that the material or construction will withstand the standard fire exposure as determined by a fire test made in conformity with the "Methods of Fire Tests of Building Construction and Materials, ASTM E119."

Fire Retardant Treated Wood - Any wood product which, when impregnated with chemicals by an approved pressure process, or by other approved means during manufactur shall, when tested in accordance with ASTM test designation E-84, have a flamespread equivalent to twenty-five (25) or less 
and show no evidence of progressive combustion when the test is continued for a period of thirty (30) minutes.

All fire retardant" treated wood products shall bear identification showing the fire hazard classification thereof issued by an approved agency having a re-examination service. Where fire retardant treated wood products are to be subjected to sustained high humidity or exposed to weather it shall be further identified as Exterior type and to indicate that there is no increase in the listed fire hazard classification when subjected to the ASTM D2898 Methods of Test for Durability of Fire Retardant treatment of Wood. Subsequent to treatment, fire retardant treated lumber and plywood shall be dried to a moisture content of nineteen (19) percent or less for lumber and fifteen (15) percent or less for plywood.

Firewall - A fire resistive wall, having protected openings, which restricts the spread of fire and extends continuously from the foundation to or through the roof.

Flame Spread - The propagation of flame over a surface.

Flame Spread Rating - That numerical value assigned to a material tested in accordance with "Methods of Test for Surface Burning Characteristics of Building Materials, ASTM E84."

$$
D-1.3
$$


Flammable - Subject to easy ignition and rapid flaming combustion.

Grade - A reference plane representing the average of finished ground ievel adjoining the building at all exterior walls.

Height - As applied to a building, means the vertical distance from grade to the highest finished roof surface in the case of flat roofs or to a point at the average height of roofs having a pitch of more than one foot in four and one-half feet.

\section{Listed - Equipment or materials included in a 1 ist} published by a nationally recognized testing laboratory, inspection agency or other organization concerned with product evaluation that maintains periodic inspection of production of listed equipment or materials, and whose listing states either that the equipment or material meets nationally recognized standards or has been tested and found suitable for use in a specified manner. The means of identifying listed equipment may vary for each testing laboratory, inspection agency, or other organization concerned with product evaluation, some of which do not recognize equipment as listed unless it is also labeled.

Load (live) - The weight superimposed by the use and occupancy of the building, not including the wind load, earth- 
quake load, or dead load.

$$
\text { Load (dead) - The vertical load due to the weight }
$$

of a 11 permanent structural and nonstructural components of a building such as walls, floors, roofs, and fixed service equipment.

Noncombustible Building Material - One which, in the form and thickness in which it is used, meets any of the following requirements:

1. Materials which pass the test procedure for defining noncombustibility of elementary materials set forth in ASTM E136 when exposed to a furnace temperature of thirteen hundred eighty-two (1382) degrees $F$. for a period of five (5) minutes, and do not cause a temperature rise of the surface or interior thermocouples in excess of fifty-four (54) degrees $F$. above the furnace air temperature at the beginning of the test and which do not flame after an exposure of thirty (30) seconds.

2. Materials having a structural base of noncombustible materials as defined in paragraph one, with a surfacing not more than one-eighth (1/8) inch thick which has a flamespread rating not greater than fifty (50) when tested in accordance with the method of test surface burning characteristics of building materials set forth in ASTM E84.

The term noncombustible does not apply to the flamespread characteristics of interior finish or trim materials. 
A material shall not be classed as noncombustible building construction material which is subject to increase in combustibility or flamespread rating beyond the limits herein established through the effects of age, moisture or other atmospheric conditions.

Owner - Any person, agent, firm, or corporation having a legal or equitable interest in the property.

Roof - The roof slab or deck with its supporting members, not including vertical supports.

Roof covering - The covering applied to the roof for weather resistance, fireresistance or appearance.

Roof structure - An enclosed structure on or above the roof of any part of a building.

Safety Glazing Materials - Glazing materials constructed, treated or combined with other materials to minimize the likelihood of injuries which result from human contact with these glazing materials.

Shaft - A vertical opening extending through one or more stories of a building, for elevators, dumbwaiter, light, ventilation, or similar purpose. 
Story - That portion of a building included between the upper surface of a floor and upper surface of the floor or roof next above.

Street - Any public thoroughfare (street, avenue, boulevard, park) or space more than twenty feet in width which has been dedicated or deeded to the public for public use.

Structure - That which is built or constructed.

Water Heater - An appliance designed primarily to supply hot water and is equipped with automatic controls 7 imiting water temperature to a maximum of 210 degrees $F$.

Yard - An open, unoccupied space, other than a court, unobstructed from the ground to the sky, except where specifically provided by this Document, on the lot on which a building is situated. 
$\theta$

$\theta$ 
APPENDIX B

BUILDING

B-101.0 General

B-101.1 Scope

The provisions contained in this Appendix shall be made part of the building section (Section B) of the document in the absence of a legally adopted Building code.

\section{$\underline{B-101.2 \quad \text { Reserved }}$}

B-101.3 Systems and Components Integral with The Building

Passive systems and components of active systems integral with the building to comply with either the Basic, Standard, or Uniform Building Code.

\section{B-102.0. Access and Location}

\section{B-102.1 Access and Location}

Solar components located over public property shall conform with the following:

(a) Every component shall be at least nine (9) feet in the clear between the lowest point of the component and a sidewalk immediately be low.

(b) A component shall not extend or occupy more than two-thirds $(2 / 3)$ of the width of sidewalk 
measured from the building, except that the component may occupy the entire width of the sidewalk provided it is fourteen (14) feet in the clear above the sidewalk.

(c) A1l combustible materials used in the construction shall be protected with not less than one (1) hour fire-resistance protection.

\section{B-103.0 Material Test and Specification}

B-103.1 Reserved

\section{B-103.2 Standards}

The following standards shall be considered as accepted engineering practice:

$\begin{array}{lll}\text { Aluminum } & - & \text { SS B-3 } \\ \text { Masonry } & - & \text { SS B-1 } \\ \text { Steel } & - & \text { SS B-4 } \\ \text { Wood } & - & \text { SS B-5 }\end{array}$

\section{B-104.0 Collectors}

\section{B-104.1 Collector Fire Resistive Requirements}

Collectors in excess of two hundred and fifty (250) square feet in base area or in excess of fifteen (15) feet in height when located on buildings more than fifty (50) feet in height shall be of non-combustible construction and shall not exceed one-third $(1 / 3)$ of the roof area off the roof on which they stand. 


\section{$\underline{B-104.2 \quad \text { Reserved }}$}

\section{B-104.3 Excavations}

Excavations adjacent to any footing shall not extend within one (1) foot of the angle of repose or natural slope of the soil under any footing or foundation unless such footing is properly underpinned or protected against settlement.

\section{B-105.0 Distribution Systems}

\section{B-105.1 Fire Rated Assemblies}

Penetration of solar distribution systems through fire rated assemblies (walls, partitions, floors, roofs, etc.) shall not reduce the fire integrity of the assembly. The penetrations shall be detailed on the plans to indicate the construction to be used to maintain the required fire resistance.

In Type I and Type II Construction materials used for solar distribution systems which do not qualify as noncombustible shall not penetrate or be concealed within any fire-resistive assembly unless enclosed by or totally embedded within non-combustible materials, unless such material and methods of penetration have been tested in accordance with SS-B-8.

\section{B-105.2 Firestopping}

All openings around exposed solar system piping shall be filled with approved non-combustible material or shall be 
closed off by close-fitting metal caps at the ceiling and floor line, and on each side of a wall or partition.

In firestopping the following materials may be used: concrete, gypsum, asbestos, mineral wool, rock wool or other approved non-combustible materials securely fastened in place to cut off drafts and provide an effective firestop.

Firestopping shall not be covered or concealed until inspected by the Enforcement Agency.

\section{B-105.3 Fire Dampers}

Fire dampers complying with the requirements of UL-555 shall be installed in the following locations, unless proper fire tests show that fire dampers are not necessary to maintain the required fire resistance:

(a) Ducts penetrating walls or partitions having a fire resistance of one or more hours. When a fire wall is of three (3) hours or greater fire resistance, a fire door meeting the requirements of SS B-9 shall be used.

(b) Ducts penetrating shaft walls having a fire resistance rating of one or more hours.

(c) Ducts penetrating floors of buildings requiring the protection of vertical openings where the duct is not protected by shafts. EXCEPTIONS: Fire dampers are not required:

(1) In buildings which do not require protected floor openings. 
(2) In duct systems serving only one floor and used only for exhaust of air to the outside and not penetrating a wall or partition having a required fire resistance rating of two (2) hours or more or passing entirely through the enclosure for a vertical shaft.

(3) Where branch ducts connect to return risers in which the air flow is upward and sub-ducts at least 22 inches in length carried up inside the riser at each inlet.

\section{B-105.4 Thermal Insulation}

105.4(a) Genera1. Where a flame spread rating or a smoke developed rating is specified in this section, such ratings shall be determined in accordance with SS B-8. Any material which is subject to an increase in flame spread rating or smoke developed rating beyond the 1 imits herein established through the effects of age, moisture, or other atmospheric conditions, shall not be permitted.

105.4(b) Foam Plastics. Foam plastic materials shall be of an approved type. Such approval shall be based on acceptable diversified tests such as, but not limited to, tunnel tests conducted in accordance with ASTM E-84-1970, Standard Method of Test for Surface Burning Characteristics of Building Materials, full scale corner tests and an ignition temperature test. 
Foam plastic having a flame-spread of 75 or less may be used in the following locations:

1. Within the cavity of a mosonry or concrete wa11.

2. On the room side surface of conforming walls or ceilings provided the foam plastic is fully protected from the interior of the building by a thermal barrier of $1 / 2$ inch gypsum wallboard or other approved material having a finish rating of not less than 15 minutes installed so as to remain in place for the required period of time.

3. Within the wall cavity of combustible non-fire resistive wall construction provided the protection is applied as described in item (2) above.

4. Within the cavity of walls classified as combustible fire resistive construction provided fire tests are conducted in accordance with ASTM E-119-1971, Fire Tests of Building Construction and Materials, and the protection from the interior of the building is at least equivalent to that required in item (2.) above. Foam plastic insulation having a flame-spread of 75 or less when tested in a thickness of 4 inches, may be used in thickness up to 10 inches in cold storage rooms, food processing rooms, ice plants and similar rooms when the room is protected with automatic sprinklers and the insulation is covered 
with $1 / 2$ inch Portland cement plaster or other approved materials having a finish rating of not less than 15 minutes. Thermal barriers shall be installed in a manner that will assure that they remain in place for the required period of time. Foam plastic insulation having a flame-spread of 25 or less may be used in a thickness of not more than 4 inches in or on walls when the foam plastic is covered by a metal facing of not less than 0.032 inches of aluminum or 26 gauge galvanized steel sheet and the insulated area is protected with automatic sprinklers. Such walls shall not be used where noncombustible or fire-resistive construction is required.

105.4(c) Cellulose Fiber. Cellulose fiber thermal insulation shall be tested in accordance with standard specification for Cellulosic Fiber (Wood-Base) Loose Fill Thermal Insulation, ASTM C-739. The insulating material shall comply with the following requirements.

1. Density: The density of the insulating material shall not exceed 3.2 pounds per cubic foot.

2. Thermal Resistance: The thermal resistance value, $R$, shall not be more than five (5) percent less than the thermal resistance value, $R$, listed for the insulating material.

3. Surface burning characteristics: The flame șpread shall not exceed twenty-five (25) when tested in accordance with ASTM E-84.

4. Flame resistance permancy: The surface burning characteristics shall not increase more than twenty (20) percent when retested using the 
two (2) foot apparatus or shall not increase when retested using ASTM E-84

5. Moisture absorbtion: The moisture absorbtion shall be no more than fifteen (15) percent by we ight.

6. Odor emission: The odor emission shall be no more than a slight trace.

7. Corrosiveness: The insulating material shall meet the test requirement as a noncorrosive insulating material.

8. Starch: The insulating material shall meet the test requirement as having no evidence of the presence of starch.

105.4(d) Concealed Insulation. Insulating materials, when concealed as installed, in buildings of any type construction, shall have a flame spread rating of not more than seventy-five (75) and a smoke developed rating of not more than four hundred fifty (450).

When such materials are installed in concealed spaces in buildings of Type III, Type V, or Type VI construction, the flame spread and smoke developed limitations do not apply to facings, provided that the facing is installed behind and within one and one half $\left(1 \frac{1}{2}\right)$ inches of the unexposed surface of non-combustible ceiling or wall finish.

105.4(e) Exposed Insulation. Insulating materials when exposed as installed in buildings of any type construction shall have a flame spread rating of not more than fifty (50) and a smoke developed rating of not more than four hundred fifty $(450)$. 
$\underline{B-105.5 \quad \text { Reserved }}$

B-105.6 Reserved

B-105.7 Reserved

$\underline{B-105.8 \quad \text { Reserved }}$

\section{B-105.9 Protection Against Vermin or Rodents}

A11 foundation and exterior wall openings around pipes, electric cables and conduits shall be protected against the passage of vermin or rodents by closing such openings with cement mortar, concrete masonry or non-corrodible metal.

\section{B-106.0 Storage systems}

\section{B-106.1 Firestopping}

106.1(a) Walls. Firestopping shall be provided in al1 wal1s to cut off al1 concealed draft openings both horizontal and vertical, and to form an effectual fire barrier between stories and between the upper story and the roof space.

Walls, including masonry walls furred with combustible material, and stud partitions shall be effectively firestopped with non-combustible material at floors, ceilings and roofs, except in those parts of a building which are framed with wood, the firestopping may be of wood not less than two (2) inches in nominal thickness. 
106.1(b) Floors. Floors of combustible materials shall be firestopped at walls and partitions where openings occur. When wood joists run parallel to a wall, the space between the wall and the nearest joist shall be not less than two and one-half $\left(2 \frac{1}{2}\right)$ inches and shall be solidly filled with non-combustible material.

Joists in all types of construction shall be firestopped at the ends and over supports for the full depth of the joists.

In firestopping, any of the following materials may be used: brick, concrete, gypsum, steel, iron, asbestos, metal lath and cement or gypsum plaster, mineral wool, rock wool, or other approved non-combustible materials, securely fastened in place to cut off drafts and provide an effective firestop. 


\author{
Appendix $\underline{\mathrm{M}-1}$ \\ Requirements for Mechanical (Air systems) \\ Access and Location
}

\title{
Outside Air Intake
}

Outside air intakes and exhaust openings for ventilating air shall be located a distance of at least ten (10) feet horizontally from any plumbing vent terminal, unless such intake opening is three (3) feet below the plumbing vent terminal. Outside air intake openings for ventilating air located in exterior walls shall be located at least ten (10) feet (measured in any direction) from any flues, vents, chimneys, gas meters, gas regulators, streets, alleys, parking lots, loading docks or other hazardous or noxious sources, unless such intake opening is three (3) feet below any vent terminal.

Exceptions to the above may be approved by the authority having jurisdiction.

Outside air intake and exhaust openings shall be located on the exterior of structures with approved projecting guards, covers or other approved means of preventing the creation of a nusiance and shall not circulate air downward in such a manner as to strike pedestrians.

Where outside ventilating air intake and exhaust openings are located in any areaway below grade, the top of the areaway shall be at least twelve (12) 
inches above the grade level and at least twelve (12) feet from the surface of any street or alley. Outside air intake and exhaust openings shall be protected by approved corrosion-resistant screens, louvers or grates.

All outside air intake and exhaust openings shall be protected against weather and water with a weather-resistant hood or louvers.

All outside air intakes shall be made and maintained easily accessible for cleaning. Outside air intake and exhaust openings shall be protected against exterior fire exposure in accordance with section $B$ of this document and the building code of the authority having jurisdiction.

Plenums: The use of unihabited basements, cellars, crawl spaces, cavity walls, areas above ceilings or attic spaces as supply, make up, exhaust air or return air plenums or ducts is prohibited. EXCEPTION: Air ceiling plenums may be installed as supply or return air plenums in all occupancies except one- and two- family dwellings, provided such air plenums meet the requirements of other applicable articles of this document and of the authority having jurisdiction and provided fuel-fired equipment or exposed combustible materials are not located therein. The use of air ceiling plenums shall be confined to one (1) fire area. The floor or roof 
assembly above an unlisted air ceiling plenum shall not depend upon the air ceiling for a portion of its fireresistive rating. Panning of the joist or stud space for return air is permitted in one- and two-family dwellings only. Crawl spaces not used as storage areas in one- and two-family dwellings may be used for air distribution systems.

Equipment in Elevator Equipment Spaces

Equipment in elevator hoistways, elevator pits, elevator machine rooms and machinery spaces: Heating and cooling equipment, ductwork or piping shall not be permitted in elevator hoistways, elevator pits, elevator machine rooms and machinery spaces except as permitted by the Safety Code For Elevators, Dumbwaiters, Escalators and Moving Walks.

\section{Materials}

One- and Two-Family Dwellings

Duct Material

Supply ducts may be constructed of approved non-combustible material constructed in accordance with Table A or in ccordance with accepted engineerin practice. Non-metallic supply ducts shall be constructed and installed in accordance with their approval and SMACNA Duct Construction Standards. 
Table A

DUCT CONSTRUCTION MINIMUM SHEET METAL GAGES

\begin{tabular}{ccc}
\hline Metal gauges (duct not enclosed in partitions) \\
\hline \\
Round Ducts \\
Minimum thickness & Minimum thickness \\
Diameter & galvanized sheet & aluminum \\
inches & gage & B\&S gage \\
Less than 12 & 30 & 26 \\
$12-14$ & 28 & 26 \\
$15-18$ & 26 & 24 \\
Over 30 & 24 & 22 \\
\hline
\end{tabular}

Rectangular Ducts

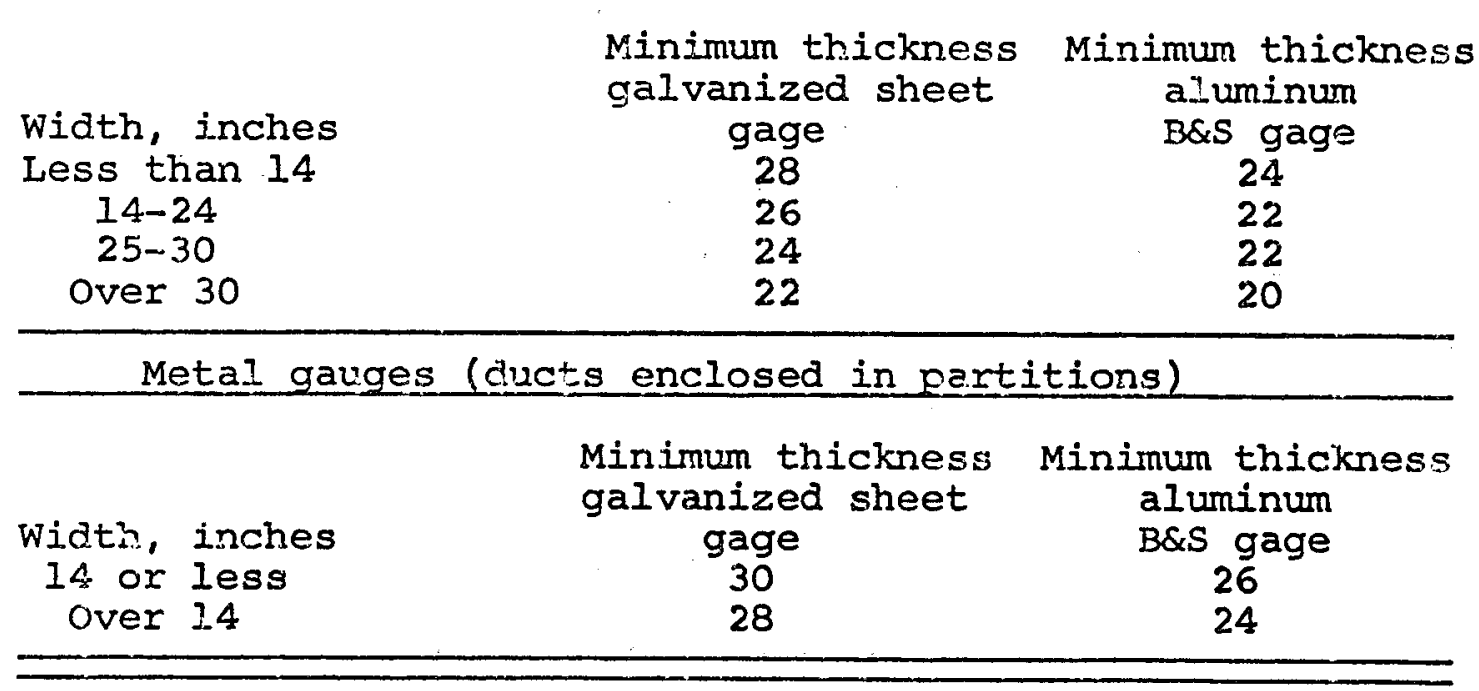

Tape used for sealing joints shall be of an approved material having a flame spread rating of twenty-five (25).

The panning of joists or studs for return air shall be of galvanized sheet metal at least Number 30 Galvanized Sheet Gaze $(0.016$ inch) or Number 26

B\&S Gage aluminum.

Underground Duct Systems

Underground duct material shall be non-combustible $M-1.4$ 
material in accordance with Table $A$.

The use of organic materials is prohibited.

Duct Coverings; Linings

Duct coverings shall have a flame spread rating not over fifty (50) without evidence of continued progressive combustion and a smoke developed rating of not over one hundred (100). Duct linings and smoke developed rating of not over fifty (50).

Other Than One- and Two-Family Dwellings

Duct Material

Ducts and plenums may be constructed of approved non-combustible material constructed in accordance with Table $B$ or in accordance with accepted engineering practice or other approved materials similar in vapor permeability, structural rigidity, air flow Eriction co-efficient, flexibility and combustibinity. Non-metallic ducts shall be constructed and installed in accordance with their approval and the SMACNA standards. Aluminum ducts shall not be used in equipment, encased in or under concrete slabs on grade, or in systems where air entering the duct is ovor two hundred fifty (250) degrees F. 
Table B

DUCT CONSTRUCTION

MINIMUM SHEET METAL

GAGES

Rectangular Ducts

\begin{tabular}{|c|c|c|c|c|}
\hline $\begin{array}{l}\text { Maximum side } \\
\text { inches }\end{array}$ & \multicolumn{2}{|c|}{$\begin{array}{c}\text { Steel } \\
\text { min.Galv.Sht.Gage }\end{array}$} & \multicolumn{2}{|c|}{$\begin{array}{l}\text { Aluminum } \\
\text { min.B\&S Gage }\end{array}$} \\
\hline $\begin{array}{l}\text { Through } 12 \\
13 \text { through } 30 \\
31 \text { through } 54 \\
55 \text { through } 84 \\
\text { over } 84\end{array}$ & \multicolumn{2}{|c|}{$\begin{array}{l}26(0.022 \text { in. }) \\
24(0.028 \text { in.) } \\
22(0.034 \text { in.) } \\
20(0.040 \text { in.) } \\
18(0.052 \text { in. })\end{array}$} & \multicolumn{2}{|c|}{$\begin{array}{l}24(0.020 \text { in. }) \\
22(0.025 \text { in. }) \\
20(0.032 \text { in. }) \\
18(0.040 \text { in. }) \\
16(0.051 \text { in. }\end{array}$} \\
\hline \multicolumn{5}{|c|}{ Round Ducts } \\
\hline \multirow[t]{2}{*}{$\begin{array}{l}\text { Diameter } \\
\text { inches }\end{array}$} & Spiral seam duct & \multicolumn{2}{|c|}{$\begin{array}{l}\text { Longitudinal } \\
\text { seam duct }\end{array}$} & Fittings \\
\hline & \multicolumn{4}{|c|}{ Steel min. Galv. Sht. Gage } \\
\hline $\begin{array}{l}\text { Through } 12 \\
13 \text { through } 18 \\
19 \text { through } 28 \\
29 \text { through } 36 \\
37 \text { through } 52\end{array}$ & $\begin{array}{l}28(0.019 \text { in.) } \\
26(0.022 \text { in.) } \\
24(0.022 \text { in.) } \\
22(0.034 \text { in.) } \\
20(0.040 \text { in.) }\end{array}$ & & $\begin{array}{l}0.022 \text { in.) } \\
0.028 \text { in.) } \\
0.034 \text { in.) } \\
0.040 \text { in.) } \\
0.052 \text { in.) }\end{array}$ & $\begin{array}{l}26(0.022 \\
24(0.028 \\
22(0.034 \\
20(0.040 \\
18(0.052\end{array}$ \\
\hline
\end{tabular}

Tape used for sealing joints shall be of an approved material with a maximum flame spread rating of twenty-five (25).

Flexible air duct material is permitted in low, medium and high pressure systems and shall conform to the requirements of UL 181. Air duct material is not limited in length.

Flexible air duct connectors are permitted in in low, medium and high pressure systems and shall conform to the requirements of UL 181. Air duct 
connectors are limited in length to fourteen (14) feet.

Flexible air duct material and flexible air duct connectors shall be subject to the following provisions: They shall be rated as class 1 when tested under application sections for flexible connectors and air ducts of the standard for air ducts: They shall not penetrate required fireresistance rated assemblies; They shall not pass through floors, walls, or ceilings; They shall not be used within six (6) feet of heating element: The temperature of the air conveyed through such connectors and air ducts shall not be more than two hundred fifty (250) degrees $F ;$ Connectors and air ducts shall conform to the applicable requirements for air ducts; Connectors and air ducts shall be installed accessible areas only; and connectors and air ducts shall be rated for the system pressure. Underground Duct Systems

Underground duct material shall be as stipulated above in one- and two-family dwellings. Duct Coverings; Linings

Duct coverings, duct linings, tapes, and core materials in panels used in duct systems shall have a flame spread rating not over twenty-five (25) without evidence of continued progressive combustion and a smoke developed rating no higher than fifty (50). If coverings and linings are to be applied with 
adhesives, they shall be tested as applied with such adhesives, or the adhesives used shall have a flame spread rating not over twenty-five (25) and a smoke developed rating no higher than (50) when in the final dry state.

EXCEPTION: Duct coverings shall not be required to meet these requirements where they are located entirely outside of a building, do not penetrate a wall or roof, and do not create an exposure hazard.

Duct coverings and linings shall not flame, glow, smolder, or smoke when tested in accordance with ASTM C4II at the temperature to which it is exposed in service. In no case shall the test temperature be below two hundred fifty (250) degrees F.

(a) One- and Two-Family Dwellings Joints and seams of ducts shall be securely fastened and so constructed as to be substantially airtight. Round pipe slip joints shall have a lap of at least one (1) inch, and each joint shall be individually fastened in an approved manner. Duct connections shall not depend entirely on soldered joints or tape. Tape used for sealing joints shall be of an approved material having a maximum flame spread rating of twenty-five (25). 
Supports and hangers for ducts shall consist of strips or rods of metal attached to joists or other framing members at intervals of not more than ten (10) feet. Nails shall not be driven through fittings or ducts at any point. Lugs or straps shall not be formed by cutting holes in fittings or ducts. The various members shall be connected so that all joints are locked, and the several members shall be attached to each other so as to be for the purposes intended airtight. 
The interior of combustible ducts shall be lined with metal at points where there is danger from incandescent particles dropping through the register, such as directly under floor register, adjacent to outdoor intakes and at the bottom of vertical ducts.

Vertical stacks for return air shall not be connected to registers on more than one (1) floor.

Air shall not be recirculated from toilet rooms, furnace rooms, boiler rooms or garages..;

Ventilation systems shall be constructed and arranged so that negative pressure from the ventilation system cannot affect the air supply for combustion nor draw products of combustion from appliances, vents or fire places.

Duct insulation shall be installed as stipulated in (b). other than one- and two-family dwellings. Installation of ducts: Ducts shall not be installed so as to impair the effectiveness of the fireprotection materials surrounding structural members of the building.

supports and hangers for ducts shall consist of strips or rods or other approved hangers of metal attached to framing members at intervals of not more than ten (10) feet. 
AIl supply, return and exhaust duct openings shall be capped with suitable material during construction.

Except when proper fire tests have shown that fire dampers are not necessary to maintain the integrity of the fireresistance rated assembly, fire dampers complying with the SMACNA Fire Damper Guilde, or UL 555, listed in Appendix $C$, shall be installed in the following locations: Ducts penetrating a fire wall. (When a fire wall is of three (3) hour or greater fire endurance, a fire door is required.) Ducts penetrating a fireresistance rated shaft wall. Sub-ducts extending twentytwo (22) inches vertically upward may be used in lieu of fire dampers for exhaust ducts. Ducts penetrating the ceiling of a fireresistance rated floor/roof-ceiling assembly. Ducts penetrating fireresistance rated corridor walls, unless the building is completely sprinklered or unless the ducts are part of an engineered smoke removal system.

Each air handling system shall be equipped with a high temperature shut-off control and disconnect switch located at a convenient accessible point adjacent to the unit for shurting down of the fan in the event of fire.

An approved smoke detection device approved for duct installation shall be installed in each $M-1.11$ 
recirculating air or exhaust system having a capacity greater than fifteen thousand $(15,000)$ cubic feet per minute (cfm). In systems between two thousand $(2,000)$ and fifteen thousand $(15,000) \mathrm{cfm}$, a heat detector shall be installed. Detection devices shall be located in the return or exhaust duct system in such a location that it will be sensing room air only. Systems designed with a separate exhaust system capable of exhausting more than fifty (50) per cent of the air supplied shall have a detection device in both the exhaust air and return air systems. Detection devices shall stop the fan(s) automatically. Detectors shall be of the manual reset type. Minimum sensitivity of approved smoke devices shall be set to operate when smoke reduces the intensity of a one (1) foot long beam of white light by four (4) per cent or the equivalent.

Negative pressure from ventilation systems: Ventilation systems shall be designed and installed so that negative pressure from the ventilation system cannot affect the air supply for combustion nor draw products of combustion from appliances, vents or fire places. Insulation

All duct systems, or portions thereof, exposed to nonconditional spaces shall be insulated to 
provide a thermal resistance, excluding film resistances, of

$R=\frac{t_{i}-t_{0}}{15}(h r)\left(s q . f t_{.}\right)(F) / 8 t u$, where $t_{i}-t_{0}$ is the design temperature differential (absolute value) between the air in the duct and the surrounding air.

EXCEPTIONS: Duct insulation, except when needed to prevent condensation, is not required in any of the following cases:

a. Where $t_{i}-t_{0}$ is twenty-five (25) degrees F. or less.

b. When the heat gain or loss of the ducts, without insulation, will not increase the energy requirements of the building.

c. Exhaust air ducts.

Where required to prevent condensation, insulation with vapor barriers shall be installed in addition to insulation required above. 
$$
.
$$ 


\section{Appendix $\underline{M-2}$}

\section{Aging Procedures}

Aging Procedure 1

Expose components or materials to simulated solar radiation (such as xenon arc radiation) for a period of 2000 equivalent sun hours. The exterior surfaces of components which are exposed to rainfall in service shall be subjected to a water spray for a period of 5 minutes during each 60 minutes of the light exposure. For components not exposed to rainfall under normal operating conditions, the water spray shall not be included in the procedure.

Aging Procedure 2

Expose components or materials to concentrated natural solar radiation using machines such as those referenced in ANSI Z97.1-1975, paragraph 4.3.2 for a period of 2000 equivalent sun hours. The exterior surfaces of components which are exposed to rainfall in service shall be subjected to a water spray for a period of 8 minutes during each 60 minutes of sunlight exposure. For components not exposed to rainfall under normal operating conditions, the water spray shall not be included in the procedure.

Aging Procedure 3

Expose components and materials to solar radiation outdoors for twelve (12) months. The average daily flux of the solar radiation, as obtained by 
Page 2

February 12, 1979

averaging the daily fluxes over the twelve (12)

month period of outdoor exposure, shall be at least

$1500 \mathrm{Btu} / \mathrm{ft} \mathrm{t}^{2}$. 


\section{Appendix $\underline{M-3}$ \\ Exposure Test}

Test specimen shall consist of a complete air or collector panel assembly.

Pre-exposure Preparation:

Air collectors shall be sealed and capped with a pressure relief device set to a value within $10 \%$ of the collector manufacturer's manimum recommended operating pressure. The inlet shall be equipped with a check valve and desiccant to allow the admission of dry air if internal pressures of less than one (I) atmosphere occur.

Exposure Conditions

Exposure conditions shall consist of 30 days cumulative exposure to a minimum daily incident solar radiation flux of $1500 \mathrm{Btu} /\left(\mathrm{ft} \mathrm{t}^{2}\right.$.day) as measured in the plane of the collector aperture. The exposure conditions shall include at least one consecutive four-hour period with a minimum flux of $300 \mathrm{Btu} /\left(\mathrm{ft} \mathrm{t}^{2} \cdot \mathrm{h}\right)$. In water filled specimens, this must occur after water boilout has occurred. The average ambient temperature shall be $80^{\circ} \mathrm{F}$ or higher during the $300 \mathrm{Btu} /\left(\mathrm{ft}^{2} \cdot \mathrm{h}\right)$ exposure time. The collector shall be mounted to a rack at a tilt angle such that the incident solar radiation during solar noon is within +100 of the normal to the plane of the aperture.

$$
M-3.1
$$


Data Records

The exposure conditions including insulation, ambient temperature, wind velocity, and precipitation shall be recorded to enable determination of the average daily values. Values shall be recorded every 30 minutes during the $300 \mathrm{Btu} /(\mathrm{ft} / \mathrm{h})$ exposure.

A regularly scheduled weekly visual inspection shall be made and a record of changes in the physical construction or appearance of the collector kept.

The results of the pre-test and post-test thermal performance shall be plotted on the same graph for comparison purposes. 


\section{APPENDIX P-1}

PLUMBING

\section{CROSS-CONNECTION CONTROL}

Sec. 1604.(a) General. 1. Measurement. The minimum required air gap shall be measured vertically from the lowest end of a potable water outlet to the flood rim or line of the fixture or receptacle into which it discharges.

2. Size. The minimum required air gap shall be twice the effective opening of a potable water outlet unless the outlet is a distance less than three times the effective opening away from a wall or similar vertical surface, in which cases the minimum required air gap shall be three times the effective opening of the outlet. In no case shall the minimum required air gap be less than shown in Table No. 16-A.

(b) Devices. Approved backflow preventers or vacuum breakers shall be installed with all plumbing fixtures or equipment, the potable water supply outlet of which may be submerged and not protected by a minimum air gap.

The potable water supply system shall be protected against backflow from the following fixtures or equipment by one or more backflow-prevention devices as indicated:

1. Low inlet to receptacles containing toxic substances (vats, storage containers, plumbing fixtures):
A. An approved air-gap fitting
B. Reduced-pressure unit
C. Pressure vacuum unit
D. Atmospheric vacuum breaker unit 
2. Low inlet to receptacles containing nontoxic substances (steam, air, food, beverages, etc.):

A. An approved air-gap fitting

B. Reduced-pressure unit

C. Pressure vacuum breaker unit

D. Atmospheric vacuum breaker unit

E. Approved double check valve assembly

3. Outiets with hose attachments which may constitute a cross-connection:

A. An approved air-gap fitting

B. Reduced-pressure unit

C. Pressure vacuum breaker unit

D. Atmospheric vacuum breaker unit

4. Coils or jackets used as heat exchangers in compressors, degreasers and other such equipment involving toxic substances:
A. An approved air-gap fitting
B. Reduced-pressure unit
C. Pressure vacuum breaker unit

5. Direct connections - subject to back pressure:

A. Nontoxic substances

(i) An approved air-gap fitting

(ii) Reduced-pressure unit

(iii) Approved double check valve assembly

B. Toxic substances

(i) An approved air-gap fitting

(ii) Reduced-pressure unit 


\section{Sewage and lethal substances}

(i) An approved air-gap fitting

(c) Approval. Before any device for the prevention of backflow or back-siphonage is installed, it shall have first been certified by a recognized testing laboratory. Devices installed in a building potable water supply distribution system for protection against backflow shall be maintained in good working condition by the person or persons responsible for the maintenance of the system.

(d) Installation. 1. Atmospheric Vacuum Breaker. Atmospheric vacuum breakers shall be installed with the critical level at least 6 inches above the flood-level rim of the fixtures they serve and on the discharge side of the last control valve to any such fixture. No shut-off valve or faucet shall be installed beyond the vacuum breaker.

2. Pressure-type Vacuum Breaker. Pressure-type vacuum breaker units shall be installed at a height of at least 12 inches above the highest fixture, tank, equipment or point of usage.

3. Reduced-pressure Backflow Preventer. A reducedpressure-type backflow preventer may be installed subject to full static pressure.

4. Equipment Connections. The supply line to steam boilers, pumps, etc., creating higher pressures than the potable water supply system shall be protected by an approved backflow prevention device installed at 1 east 12 inches above the surrounding ground or floor.

$$
P-1.3
$$


5. Access. Backflow-and back-siphonage-preventing devices shall be accessibly located in the same room with the fixture, tank or equipment they serve.

6. Location. In the installation of the following list of fixtures and devices, where an air gap is not provided or is impracticable, approved backflow preventers shall be installed in all supply lines according to Table No. 16-B.

(e) Tanks and Vats. 1. Where a potable water outlet terminates below the rim of a tank or vat and the tank or vat has an overflow of diameter not less than given in Table No. 16-C, the overflow pipe shall be provided with an air gap as close to the tank as possible

2. The potable water outlet to th tank or vat shall terminate a distance not less than one and one-half times the height to which the water can rise in the tank above the top of the overflow. This level shall be established at the maximum flow rate of the supply to the tank or vat and with all outlets closed except the air-gapped overflow outlet.

3. The distance from the outlet to the high water level shall be measured from the critical point of the potable water-supply outlet.

(f) Barometric Loop. Water connections not subject to back pressure where an actual or potential backflow or backsiphonage hazard exists may, in lieu of devices specified in Section 1604, be provided with a barometric 100p. Barometric loops shall precede the point of connection.

$$
P-1.4
$$


TABLE NO. 16-A - MINIMUM AIR GAPS FOR PLUMBING FIXTURES

MINIMUM AIR GAP
When not Affected
by Near Wall (inches)

FIXTURE

\begin{tabular}{l} 
FIXTURE \\
\hline Effective opening not \\
greater than $1 / 2-$ inch \\
diameter
\end{tabular}

Effective openings not greater than $\frac{1}{4}$ inch diameter

Effective openings not greater than 1-inch diameter

Effective openings greater than one inch

Effective opening not greater than 1/2-inch inch
1

When Affected

by Near Wa $11^{2}$ (inches)

$1 \frac{1}{2}$
$1 \frac{1}{2}$

2

$2 x$ diameter of
effective openi
$2 \frac{1}{4}$

3

$3 x$ diameter of

effective opening

Ade walls, fibs or similat obstructions do sot affect eit eaps when spaced from inside edge of pout openins a distance greater than three time the dinmeter of the effective opening for a ingle wall. of a distance grealer than four times the dimmeter of the effective opening for two bersecting walls.

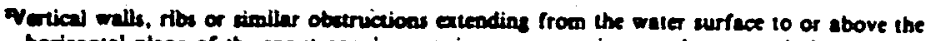
corisontal plane of the spoul openins require e reater air eap when spaced closer to the nevea inside edre of apout opening thas speciried is Foocacte I above. The effect of three or

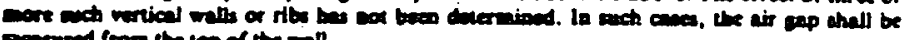
Baserent frose the lop of the wall. 
$$
.
$$ 


\section{INDIRECT AND SPECIAL WASTE PIPING}

\section{Nr Gap and Alr Break}

Sec. 1301. (a) Air Gap. The air gap between the indirect waste and the building drainage system shall be at least twice the effective diameter of the drain served and shall be provided by one of the following methods:

1. Extend the indirect waste pipe to an open, accessible individual waste ink, floor drain or other suitable fixture which is properly trapped and vented. The indireet waste shall terminate a sufficient distance above the nood-level rim of the receiving fixture to provide the required air gap and thall be installed in accordance with this code.

2. Provide an air gap in the drain connection on the inlet side of the trap which receives the waste from the indirect waste.

(b) Ar Break. When an air break is required between the indirect waste and the building drainage system, the discharge pipe shall be extended below the flood-level rim of the receptacie a sufficient distance to prevent splashing or flooding.

\section{indirect Waste}

Sec. 1302. (a) General. All indirect waste piping shall discharge into the building drainage system through an air gap or air break as set forth in this code.

(b) Materials. Indirect waste piping shall meet the material, pipe sizing

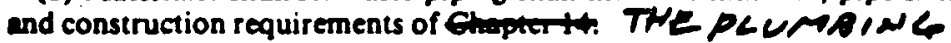

(c) Trap. Any indirect waste pipe exceeding 5 feet in length shall be trapped. This requirement does not apply to indireet waste pipes carrying clean water waste only.

(d) Ready Aceess. Indirect waste piping shall be so installed as to permit ready access for fushing and cleansing.

(e) Where Required. II. Food-hnodling Establisbmeats. In the case of Tood-handling establishments engaged in the storage, preparation, sellirs. ervme processing or other handling of foods, indirect waste pipins shall be providuhfor refrigerator coils, walk-in freezers, ice boxes ice-making machines, stearmtextles, steam tables, potato peelers, en boilers, coffee urns and similar types or waclosed equipment.

The foregoing does not apply to any dishwasting or culinary sink in any food preparation room, unless such Te-abble is used for soaking or washing ready-lo-serve food.

The indirect waste shall discher through an air 8 en or air break into a trapped and vented receptor acept that an air gap is requnnd where the indirect waste pipe may bernder vacuum (less than atmospheric paessure).

Multiple-comn.rment sinks, including bar sinks, shall be instalteorwith en indireg connection from each compirtment arranged to discharge 
through an air gap. Three such indirect drains may discharge thto a single Itapped branch.

These paragraphs do not apply to private jing quarters or dwelling units.

2. Bar and Fountain Str. Frang. Whin sinks in bars, soda fountains and counters are so located that the refpsacying such sinks cannot be vented, the sink drain shall dischage through an atreap or air break into a floor train or sink which is properly trapped and vented.

3. Sterilizes Appliances, devices or apparatus such andills, sterilizers and simila equipment requiring waste connections and used fac sterile maxtials shall be directly connected by means of air rap

4. Air conditioning Equipment. No evaporative cooler, air washer, airhandling or similar air-conditioning equipment shall have any drain pipe in connection therewith directly connected to any soil, waste or vent pipe. Such equipment shall be drained by means of indirect waste pipe. The indirect waste shall discharge through an air gap or air break into an open floor sink, floor drain or other approved-type receptor which is properly connected to the drainage system or other approved point of disposal, except that an air gap is required where the indirect waste pipe may be under vacuum.

5. Drips or Drainage Ovtlets. Appliances, devices or apparatus not regularly classed as plumbing fixtures but which have drips or drainage outets mas be drained by indirect waste pipes discharging into an open receptable through either an air gap or air break shatt bedtermined ty thabuituing offriate

6. Pressure Tanks, Bollers and Relieve Valves. The drains from pressure tanks, boilers, relief valves and similar equipment may discharge indirectby to the drainage system by means of an air gap and without any traps or vents on the indirect pipins.

7. Water Distribotion System. Indirect waste connections shallbe provided for 8ranis, omanaus or relief pipes from the water distribution system by means of an air gap.

(f) Driaking Eawmiths. Drinking fountain wastes may be moinactly connected. ivesplore ano SUmps

Sec. 1303. (a) Where Required. The receptor must be located so that the required air gap between the indirect waste line and receptor can be maintained under all conditions of backflow. If this is not possible, then the receptor at such a location must be a sump installed ascroquired under Sas. I ins-1406 acthiscode, and the discharge must be indirectly connected to the building drainage system as required by Section 1302 (a).

(b) Location. Waste receptors or sumps serving indirect waste pipes shall not be installed in any toilet room nor in any tilated space such as a closet or storeroom.

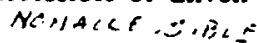

(c) Problbited Receptors. No plumbing fixture which is used for

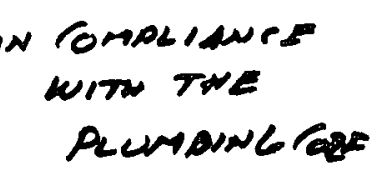


domestic or culinary purposes shall be used to receive the discharge of an

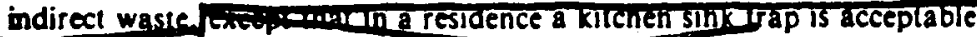
Tor use as a receptor for a dishwashe a d a receptor for a clothesmusillns machine.

(d) Desige. All plumbing receptors receiving the discharge of the indirect waste pipes shall be of such shape and capacity as to prevent splashing or flooding.

(e) Straloers and Baskets. Every indirect waste receptor shall be equipped with a readily removable metal basket over which all indirect waste pipes shall discharge, or the indirect waste receptor outlet. shall be equipped with a beehive strainer not less than four inches in height. This does not apply piper waste only.

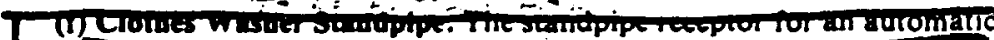

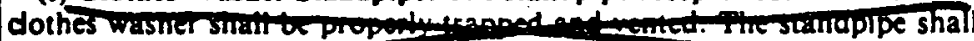

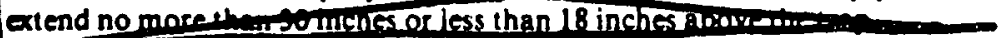

\section{Waste Water Tomperature}

Sec. 1304. No steam pipe shall connect to any part of a drainage or plumbing system, nor shall any water above $140^{\circ} \mathrm{F}$. be discharged into any part of a drainage system. Such pipes shall be connected by discharging in. to an indirect waste receptor connected to the drainage system.

\section{Clear Water Wastes}

Sec. 1305. Water lifts, expansion tanks, cooling jackets, sprinkler systerns, drip or overflow pans or similar devices which waste clear water only, when emptying into the building drainage system, shall discharge through an indirect waste by means of an air gap.

\section{Nrconditioning Condensate}

Sex. 1306. (a) Slze. Air-conditioning condensace and waste pipes shall not be directly connected to any drainage system and shall not be smaller than:

$$
\begin{aligned}
& \text { \% inch-minimum size through } 3 \text { tons } \\
& I \text { inch-serving through } 20 \text { tons } \\
& 1 \% \text { inch-serving through } 100 \text { tons }
\end{aligned}
$$

When discharge is greater than $7 \%$ gallons per minute, the waste pipe shall be sized as drainage piping in accordance with seation pur The

(b) Discharge. Unless expressly prohibited, air-conditioning condensate rage waste pipes shall discharge as follows:

1. Indirectly to a properly trapped fixture as required in Section 1301 (a).

2. Indirectly to a sump pump.

3. Indirectly to the building storm drain.

4. An approved leaching well or comparable arrangement.

74 


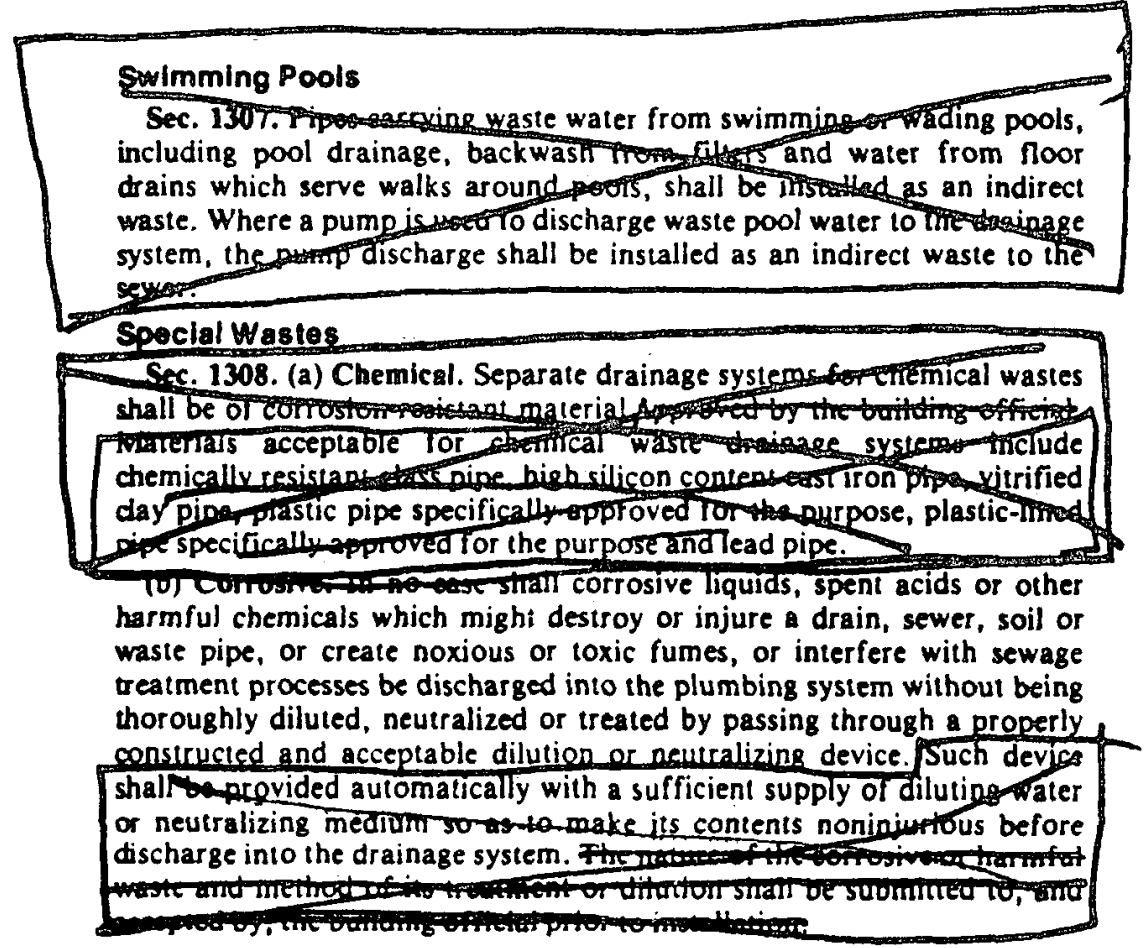




\section{PLUMB ING}

NOTE: Abbreviations in Table No. 6-A refer to the following organizations:

ANSI

American National Standards Institute 1430 Broadway

New York, New York 10018

ASSE American Society of Sanitary Engineering

960 Aluminating Building

Cleveland, Ohio 44113

ASTM American Society for Testing and Materials

1916 Race Street

Philadelphia, Pennsylvania 19103

AWWA American Water Works Association

6666 West Quincy Avenue

Denver, Colorado 80235

CISPI Cast Iron Soil Pipe Institute

2029 K Street, N.W.

Washington, D. C. 20036

CS Commercial Standards, Commodily Standards Division Office of Industry and Commerce

U.S. Department of Commerce

Washington, D. C. 20230

FS

Federal Supply Service, Standards Division

General Services Administration

Washington. D. C. 20405

\begin{tabular}{ll|}
\hline InPMO & International Association of Plumbing and \\
\hline MSS & Los Angeles, California 90032 \\
\hline $\begin{array}{l}\text { Manufacturers Standardization Society of the Valve } \\
\text { and Fittings Industry, Inc. } \\
\text { 1815 North Fort Myer Drive } \\
\text { Aslington, Virginia } 22209\end{array}$
\end{tabular}

NSF

National Sanitation Foundation

Ann Aubor, Michigan 48106

PDI Plumbing and Drainage Institule 5342 Boulevard Place Indianapolis, Indiana 46208

UL Underwriters Laboratories, Inc.

207 East Ohio Street

Chicago, Illinois 606:11

$$
P-3.1
$$


TAGLE MO. QA

STAMDAADS FOR APPAOVED PLUMBINO MATEAIALS AMD EOUIPMENT

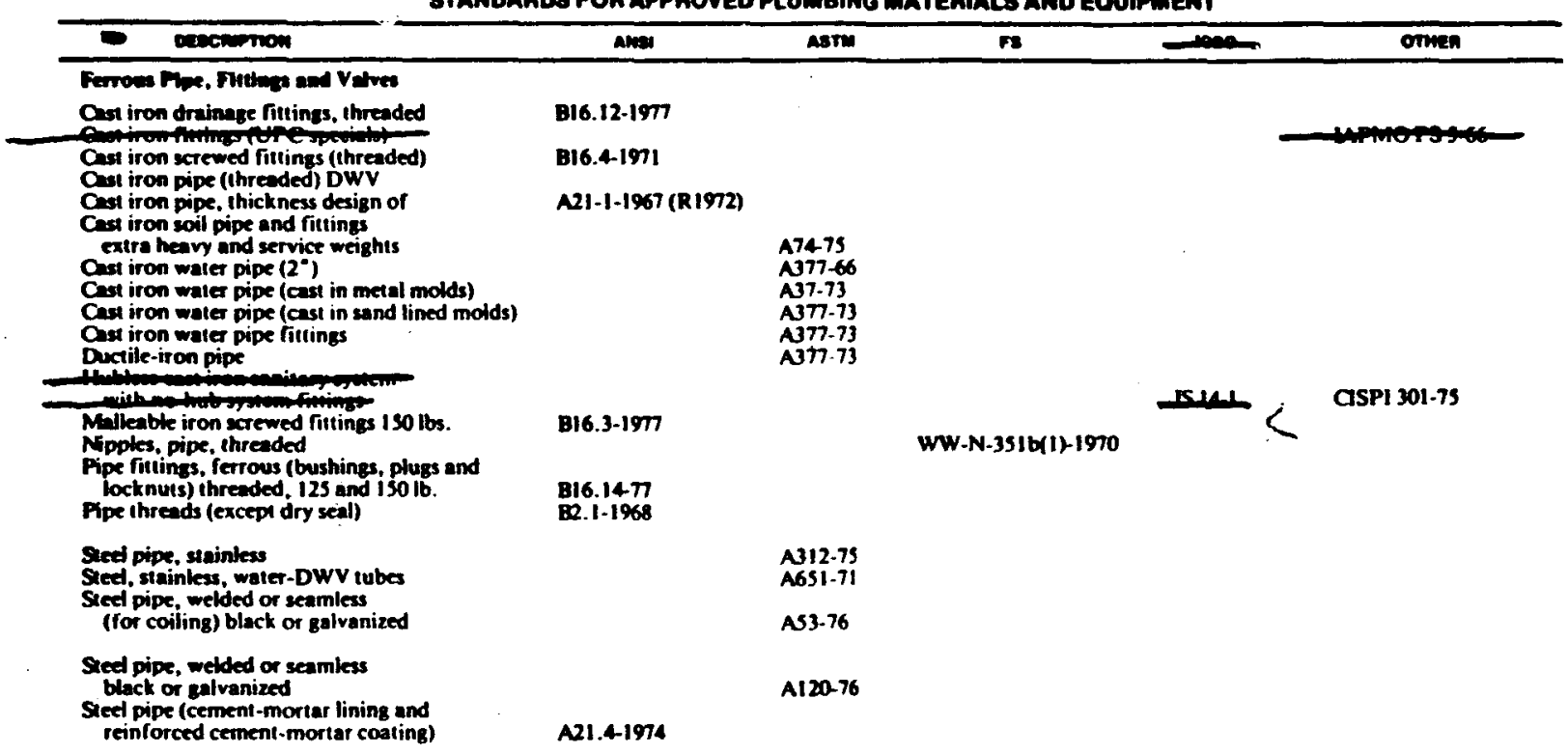


TABLE MO. QA lcontinued

STANDARDS FOA APPROVED PLUMBINO MATERIALS AND EOUIPAEMT

\begin{tabular}{|c|c|c|c|c|c|}
\hline axconomon & AMES & Astm & $\boldsymbol{m}$ & $x=0$ & onven \\
\hline 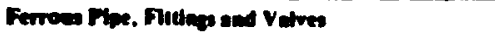 & & & & & \\
\hline 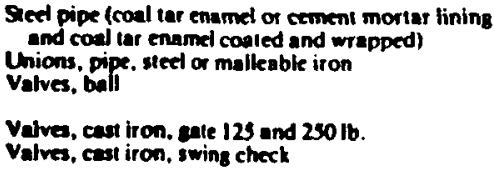 & & & $\begin{array}{l}\text { WW-P.1432-1970 } \\
\text { WW-U-531c-1965 } \\
\text { WW-V-35a-1965 } \\
\text { In Amend 2-1970 } \\
\text { WW.V-58b-1971 }\end{array}$ & & MSS-SP-71-1970 \\
\hline 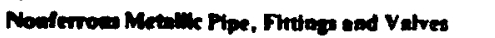 & & & & & \\
\hline 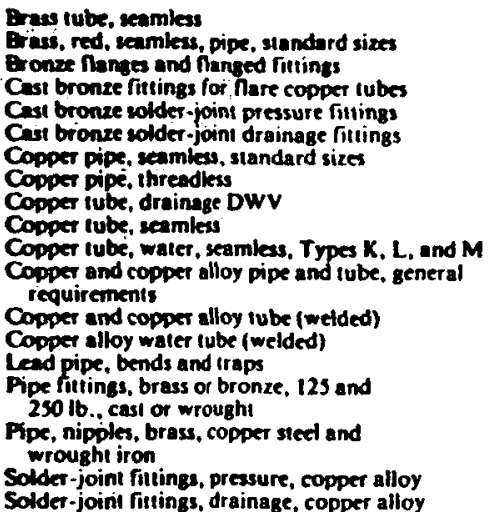 & $\begin{array}{l}\text { B16.19-1971 } \\
\text { B16.22-1973 } \\
\text { B16.29-1973 }\end{array}$ & $\begin{array}{l}\text { B135-74 } \\
\text { B43.76 } \\
\\
\text { B42-76 } \\
\text { B302-76 } \\
\text { B305-76 } \\
\text { B59-76 } \\
\text { B88.76 } \\
\text { Bes1.76 } \\
\text { BS43.72 } \\
\text { Bs86.73 }\end{array}$ & WW-P.325.1974 & & \\
\hline
\end{tabular}


TABLE MO. EA (comtinniod)

STANDARDS FOA APPAOVEO PLUMOINO MATERIALS AND ECUIPMENT

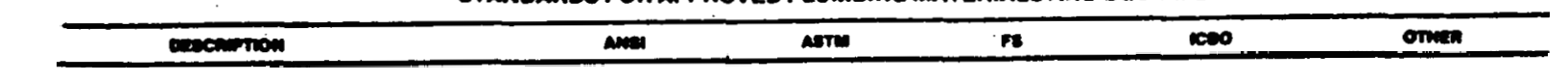

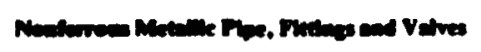

Unions, brese or bronse, $250 \mathrm{lb}$.

Velve, ball, copper alloy, iron or steel

Vaver, eate, brones, threaded and nanged

Vulva, ande, cheect and flobe, bronxe, $125 \mathrm{lb}$.

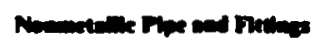

Abbestos cement nompressure sewer pipe A sbertos cement noppreas

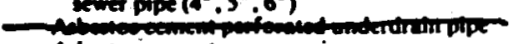

Alberos cement pressure pipe

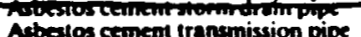

Alossos cemem iranemission pipe

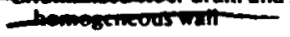

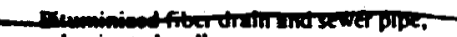

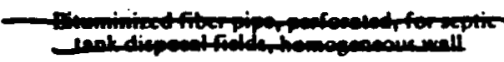

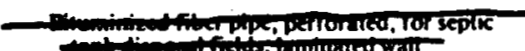

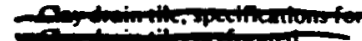

Qey pipe, standard and extra strength

Coype. sondard and extra strength

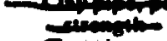

WW.U. $16160-1967$

Ww.V.35a-1955

inw-V-s4-196\%

in Amend 1-1970

wW.V-51d-1967

C128-76

Os4.76

C2\%-76

0668.736

$\rightarrow 00000$

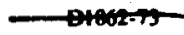

$\rightarrow 2012-9$

meangrs

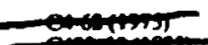

c700-75

Croa-7s

[5 14-3

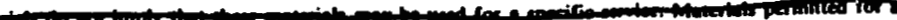

- 
STANOAAOS FOA APPROVED PLUMBINO MATERIALS ANO EOUIPMENT

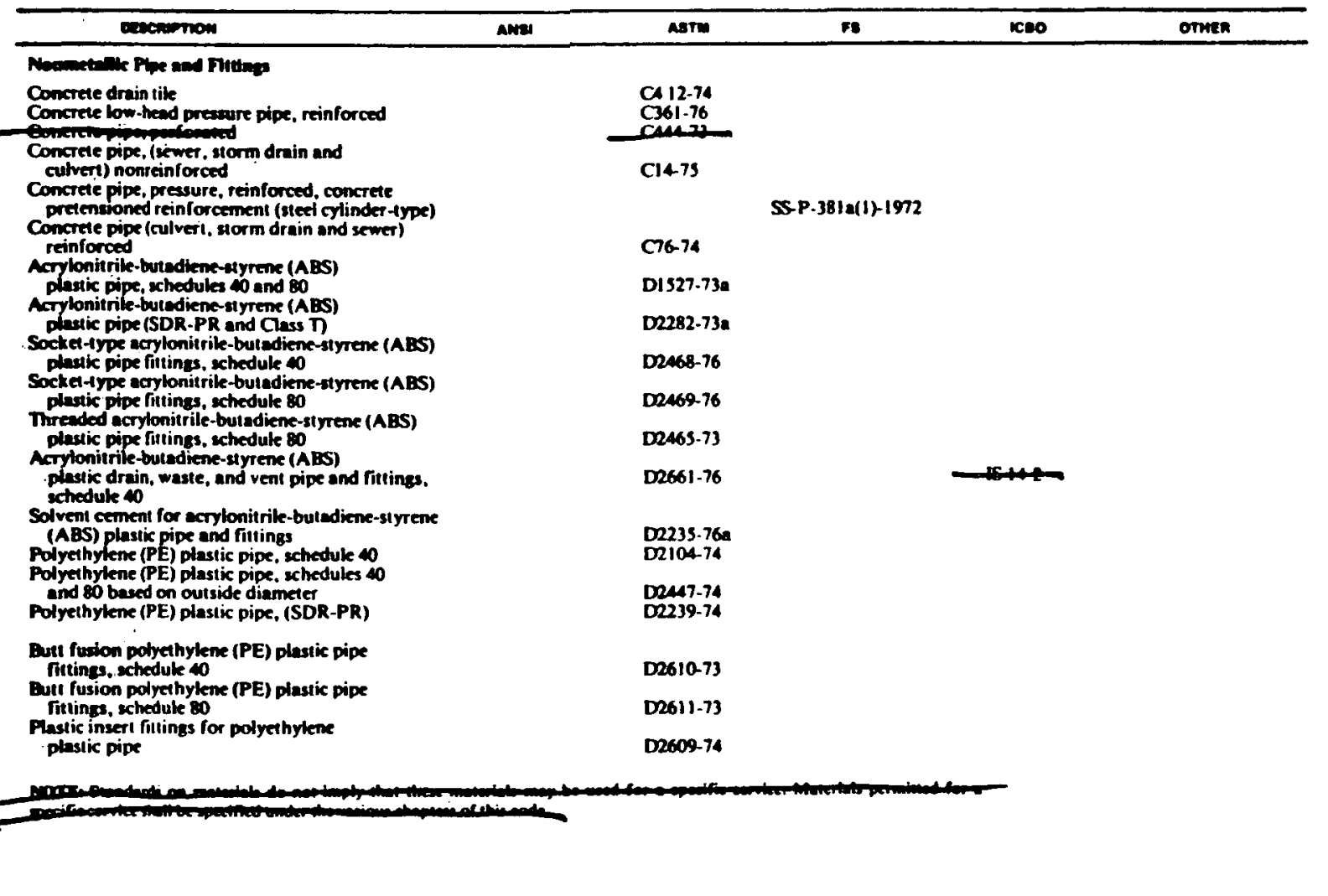


s

TADLE mo. aAcommmon

STANDARDS FOM APPAOVED PLUMOUNO MATERIALS AND EOUIPMENT

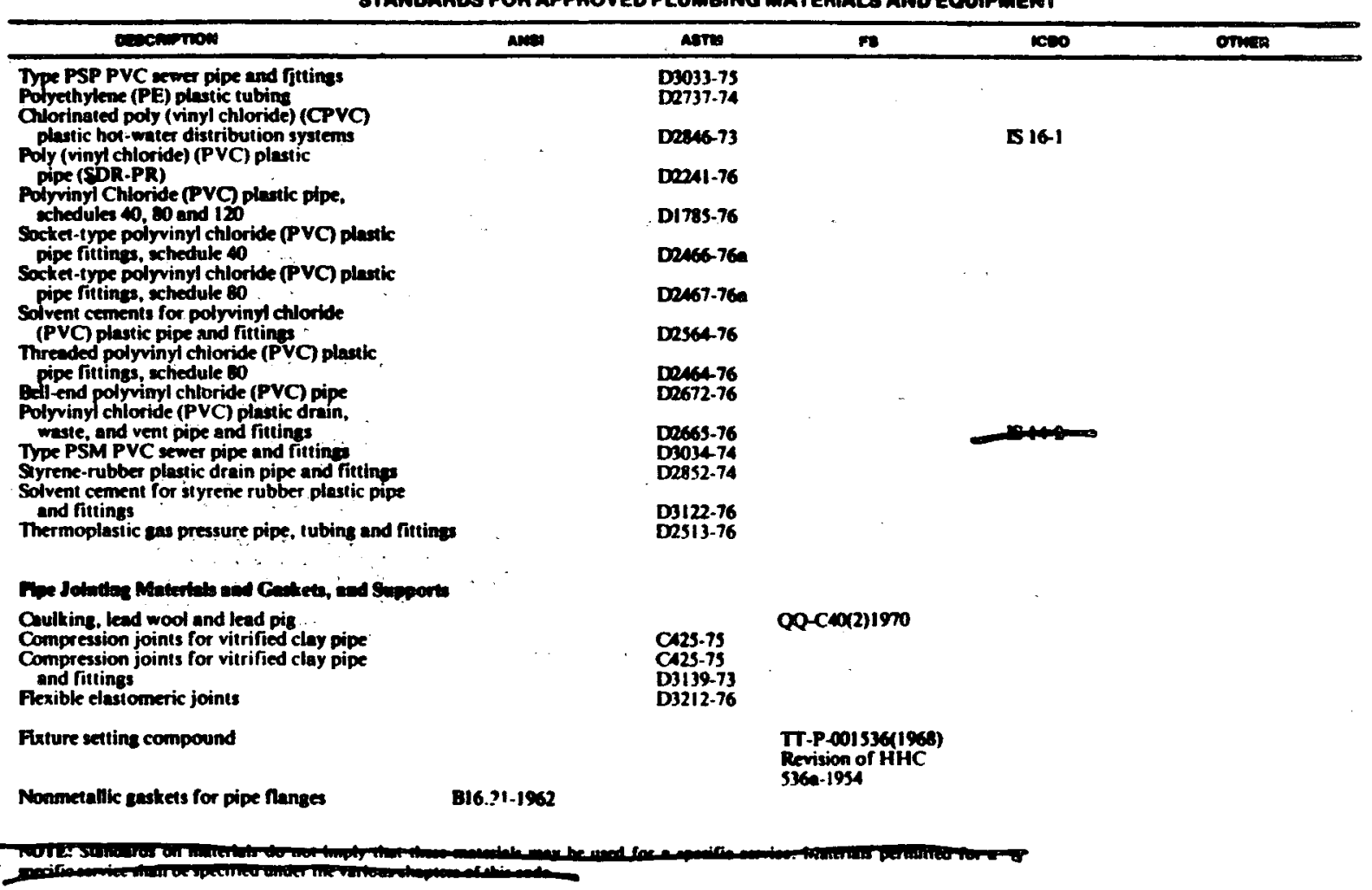


TAQLE MO. OA contimoon

STAMDARDS FOA APPAOVED PLUMBINO MATEAIALS ANO EQUIPMENT

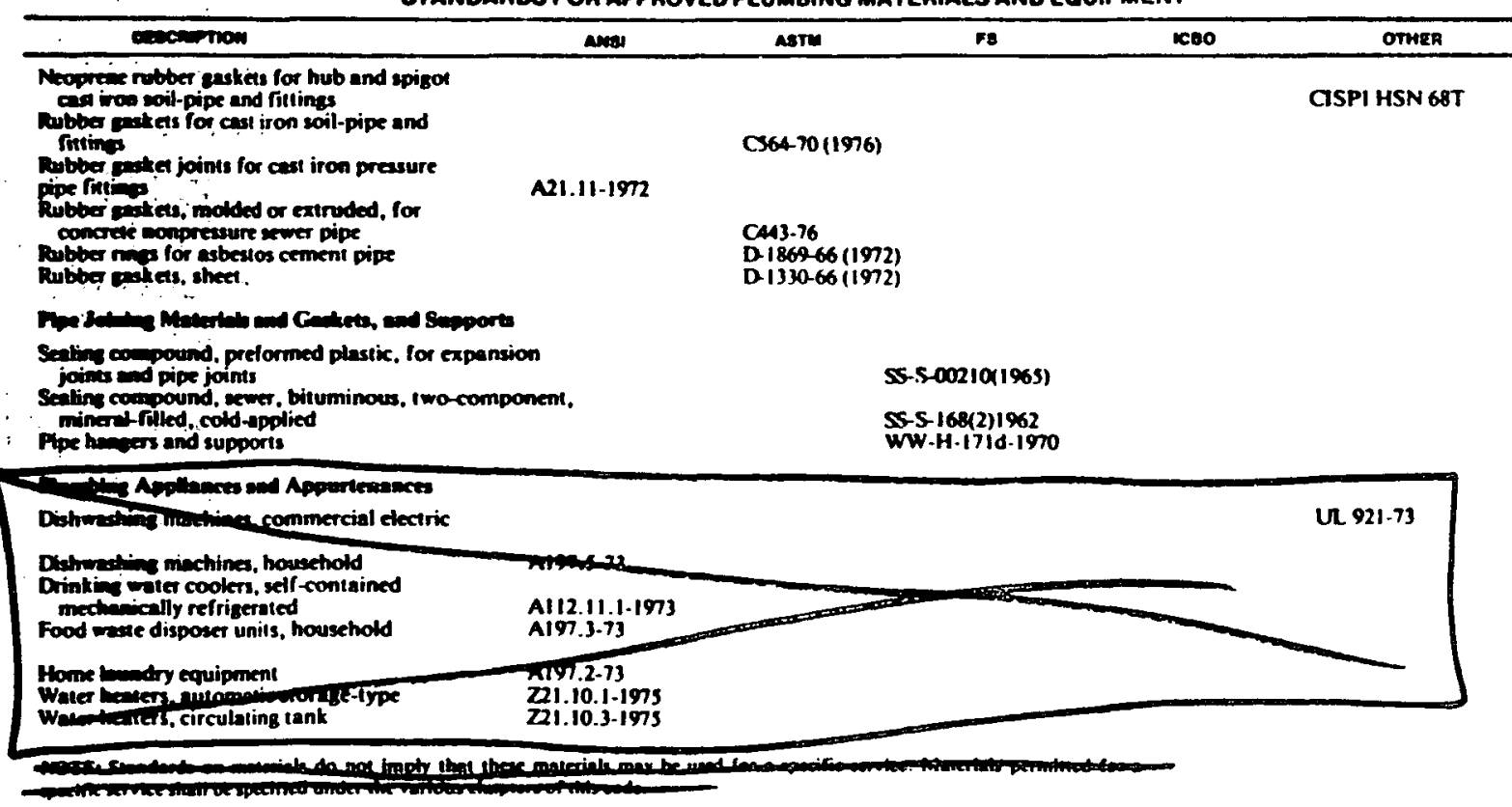


TABLE NO. QA COOMthUSO

STANOAROS FOR APPAOVED PLUMBING MAATERIALS AND EOUIPMENT

\begin{tabular}{|c|c|c|c|c|c|}
\hline Docicuption & ANBI & ABTES & 58 & CEOO & OTMER \\
\hline \multicolumn{6}{|l|}{ Bact now Prevediers } \\
\hline $\begin{array}{l}\text { Vecuum breakers, antisiphon } \\
\text { Yacuum breakes, hose conection } \\
\text { Double check with aumospheric vent } \\
\text { Reduced pressure zome device } \\
\text { Double check valve assembil } \\
\text { Vacuum breakers, pressure-iype }\end{array}$ & & & & & $\begin{array}{l}\text { ASSE 1001 } \\
\text { ASSE 1011 } \\
\text { ASSE } 1012 \\
\text { ASSE } 1013 \\
\text { ASSE } 1013 \\
\text { ASSE } 1020\end{array}$ \\
\hline \multicolumn{6}{|l|}{ Mascetionerses } \\
\hline Air gap standards & $\begin{array}{l}\text { Al12.1.2-1942 } \\
\text { (R1973) }\end{array}$ & & & & \\
\hline $\begin{array}{l}\text { Arreaters, water hammet } \\
\text { Enamel, cool-tar, (protective coating) } \\
\text { Camps, hose }\end{array}$ & Al12.26.1-1969 & & $W W-C-40 B(a)-1969$ & & AWWA C203.73 \\
\hline $\begin{array}{l}\text { Coeting, pipe, thermoplastic resin or } \\
\text { thermoseting, epoxy } \\
\text { Connector, walc. fexible copper } \\
\text { Copper, sheet and sirip for building } \\
\text { construction }\end{array}$ & & & LCC3308-1970 & & LAPMO PS-1473 \\
\hline 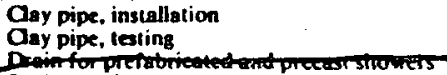 & & 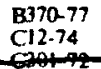 & & & 8 \\
\hline 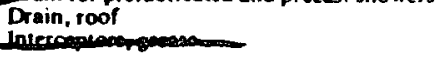 & Al12.21.2.1971 & & & & Dof \\
\hline $\begin{array}{l}\text { Lead, sheet, grade A } \\
\text { Relief valves, automatic }\end{array}$ & $\begin{array}{l}21.22-191 \\
214\end{array}$ & & $00-L-201 f(2) 1970$ & & \\
\hline
\end{tabular}


TABLE ANO. QA (continuod)

8TANDARDS FOR APPAOVEO PLUMBINO RAATERIALS AND EQUIPMENT

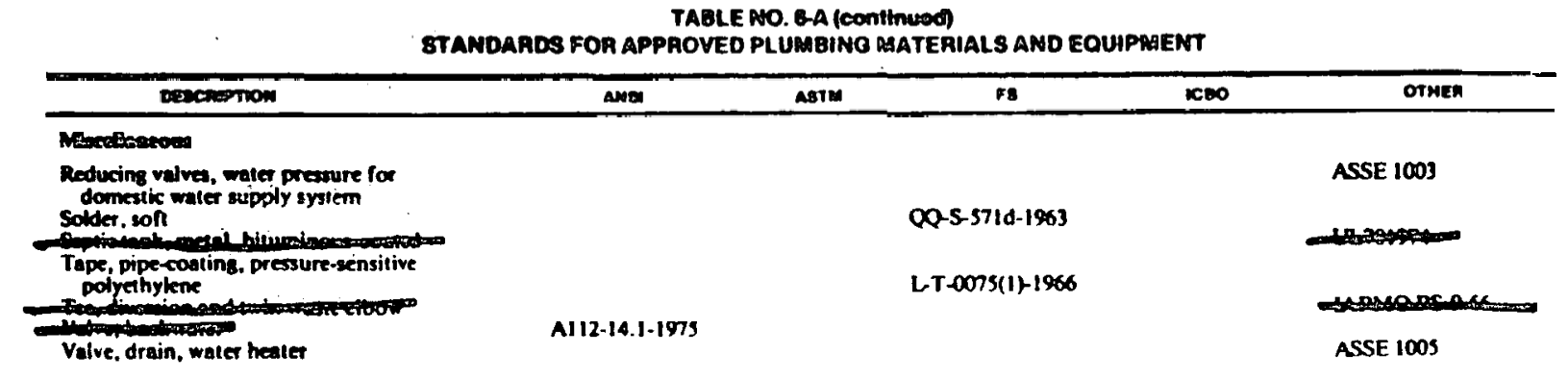
Dedis 
$$
.
$$ 
APPENDIX $P-4$

PLUMB ING

Generally Acceptable and Unacceptable Use Cond1tions for Metals in Direct Contact with Heat Trans fer Llquids in Open Systems

Cenerally Dnacceptable Use Conditions

Cenerally Acceptable Use Conditions 1 /

\section{Alumi num}

1. When in direct contact with untreated tap water with pt $<5$ or $>9$.

2. When in direct contact with aqueous liquid containing less electro positive metal lons such as copper or 1 ron or hallde lons.

3. When specific data regarding the behavior of a particular alloy are not avallable, the velocity of aqueous 11quid shall not exceed $4 \mathrm{ft} / \mathrm{sec}$.

4. When in direct contact with a liquid which is in contact with corrosive fluxes.
1. When in direct contact with diseliled or delonized water which contalns appropriate Inhib1tors and does not contact copper or 1ron.

2. When in direct contact with diatilled or delonized water which contalns approprlate Inh 1b1tors and a weans of removing heavy wetal lons obtained from contact with copper or Iron.

3. When in direct contact with stable anhydrous organic liquids. 


\section{Copper}

1. When In direct contact with aqueous liquid contalning high concentrations of chlorldes. sulfates or 11quid wich contalns hydrogen sulf1de.

2. When in direct contact with chemicals that can form copper complexes such as ammonium compounds.

3. When in direct contact with an aqueous liquid having a veloc1ty greater than $4 \mathrm{ft} / \mathrm{sec} . \underline{2} /$

4. When in direct contact wth a liquid which is in contact with corrosive fluxes.

5. When in contact with an aqueous liquid with a $\mathrm{pH}$ lower than 5 .

6. When the copper surface is Inttially locally covered with a copper oxide film or a carbonsoceous E11m.

7. When operat ins under conditions conductive to water line corrosion.
1. When in direct contact with distilled, delonized or low chloride, low sulfate and low sulf1de tap water.

2. When in direct contact with stable anhydrous organic liquids.

\section{Steel}

1. When in direct contact with untreated tap, distlled or delonlsed water with pH $<5$ or $>12$.

2. When in direct contact wth a liquid wich is In contact with corrosive flures.
1. When in direct contact with distilled, delonized or low -alt content water which contalns appropriate corrosion inhibitors.

2. When in direct contact with ctable anhydrous organic llquids. 


\section{Steel (contd.)}

3. Then In di rect contact with an aqueous liquid having a velocity greater than $6 \mathrm{ft} / \mathrm{sec} . \underline{2}$
3. Then adequate cathodic protection of the steel is used (practical only for storage tanks).

4. When operating under conditions conduclve to water line corrosion.

\section{Stainless Steel}

1. When the grade of stalnless steel selected is not corrosion resistant in the anticipated heat trans fer liquid.

2. Then in direct contact with a ilquid wich is in contact with corrosive fluxes.
1. When the grade of stainless steel selected is res 18 tant to pltting, crevice corrosion, Intergranular attack and stress corrosion cracking in the anticipated use conditions.

2. When In direct contact with otable anhydrous organic liquids.

\section{Galvanized Steel}

1. When in direct contact with aqueous liquid contining copper lons.

2. When in direct contact with aqueous l1quid with $\mathrm{pH}<7$ or $>12$.

3. When In direct contact with aqueous liquid with a temperature $>55 \mathrm{C}$.
1. When adequate cathod1c protection of the galvanized parts 1s used (practical only for storage tanks).

2. When in contact with stable anthdrous organic liquids. 


\section{Brass and Other Copper Alloys}

Binary copper-zinc brass alloys (CDA 2 XOX serles) exhibit generally the same behavlor as copper when exposed to the same conditions. Horever, the brass selected shall resist dezincification in the operating conditions anticipated. At zinc contents of $15 \%$ and greater, these alloys becone Increasingly subceptlble to stress corrosion. Selection of brass with a zinc content below 152 is advised. There are a variety of other copper alloys avallable, notably copper-nickel alloys. Which have been developed to provide Improved corrosion performance in aqueous environments.

$1 /$

The use of sultable antifreeze agents and buffers is acceptable provided they do not promote corrosion of the wetall1c liquid contalment syotem. The use of suitable corrosion Inhibitors for specific metals is acceptable provided they do not prosote corrosion of other wetals present in the systen. If thermal or chemlcal degradation of these compounds occurs, the degradat10n products ohall not promote corrosion.

\section{I}

The flow rates at which erosion/corrosion becowes ignificant will vary wth the conditions of operation. Accordingly, the value listed is approxinate. 
Generally Acceptable and Unacceptable Use Cond1tions for Fatals In Direct Contact With Heat Tran fer

ilquids in Closed Syotems

Generally Unacceptable Use Conditions

Cenerally Acceptable Use Conditions $1 /$

\section{Aluminum}

1. When in direct contact with untrested tap water with pit $<5$ or $>9$.

2. When in direct contact with liquid contalning copper, iron or hallde lons.

3. When specifled date regarding the behavior of a particular allog are not avallable, the velocits of aqueous llquids ahall not exceed 4 Et/sec.
1. When In direct contact with distlled or delonized water wich contalns appropriate corrosion inhibitors.

2. When in direct contact with atable anhydrous organic 11quids.

\section{Copper}

1. When in direct contact with an aqueow 11quid have a velocity greater than $4 \mathrm{ft} / \mathrm{sec}$. $2 /$

2. When In contact with chemicalo that can form copper complexes such as ameonium compounds.
1. When in direct contact with untreated tap, dietilled or delonised water.

2. When in direct contact with -table anhydrous organic 11quida.

3. When In direct contact with aqueous 11quids which do not for complexes wh copper. 
4930.2

Cenerally Unacceptable Uae Condielons

Generally Acceptable Use Cond1t1ons II

\section{sceel}

1. When in direct contact wh liquid having a velocicy greater than $6 \mathrm{ft} / \mathrm{sec} .2 \mathrm{I}$

1. When in direct contact with untreated tap, dlatilled or delontzed water.

2. When In direct contact wh untreated tap, distilled or delonized water with pH $<5$ or $>12$.

2. Then in direct contact with atable anhydrous organic Ilquids.

3. When in direct concact wh aqueous llquids of $5<\mathrm{pH}<12$.

\section{Stalnless Steel}

1. Then the grade of ataless steel -elected is not corrosion resistant In the anticipated heat tronsfer 11quid.

2. When In direct contact th a liquid wich is in contact at th corrosive tlures.
1. then the grade of stainless oteel selected is res $18 \tan t$ to pitting, crevice corrosion, Intergranular at tack and stress corrosion cracking in the anticipated use conditions.

2. When in direct concact wh scable anhydrous organic liquids.

\section{Galyonized Steel}

1. When in direct contact with water of th $\mathrm{pH}<7$ or $>12$.

2. then In direct contact wh an aqueous 1squid oth cemperature $>55 \mathrm{C}$.
1. then in contact with water of $\mathrm{pH}>7$ but $<12$. 


\section{Brass and Other Copper Allogs}

BInary copper-zinc brass alloys (CDA $2 \times X X$ serles) exhlblt generally the same behavior as copper when exposed to the same conditlons. However, the brass selected shall resist dezincification in the operating conditions anticipated. At zinc contents of $15 \%$ and greater, these alloys become increasingly ausceptible to atress corrosion. Selection of brass wt th a zinc content belos $15 \%$ is advised. There are a variety of other copper alloys avallable, notably copper-nickel alloys, which have been developed to provide improved corrosion performance in aqueous environments.

\section{$1 /$}

The use of sultable antifreeze agents and buffers is acceptable provided they do not promote corrosion of the metallic liquid contalnment aysem. The use of sultable corrosion inhlbitors for specific metals lo acceptable provided they do not promote corrosion of other tals present in the gystem. If thermal or chemlcal degradation of these compounds occurs, the degradation products ahall not promote corrosion.

2I

The flow rates at which erosion/corrosion becomes signiflcant will vary wth the conditions of oderation. Accordingly, the value listed is approximate. 
$$
.
$$ 


\section{Chapter 15 \\ MECHANICAL REFRIGERATING EQUIPMENT} Scope

Sec. 1501. All mechanical refrigerating systems and equipment shall conform to the requirements of this Code.

A label of an approved agency, which is attached to the equipment, will be accepted as evidence that the equipment is approved.

Refrigerating systems and equipment, including the replacement of parts and alterations, shall comply with the provisions of this Chapter.

\section{Refrigerents}

Sec. 1502. The refrigerant used shall be of a type listed in Section 1503 unless the Building Official finds that a proposed refrigerant is no more hazardous to life, limb, health, or property than the type listed.

Classification of Refrigerants

Sec. 1503. (a) Group 1. The following refrigerants shall be classified as Group 1 refrigerants:

\begin{tabular}{|c|c|c|}
\hline $\begin{array}{l}\text { aemigeranT } \\
\text { DESIGMATION }\end{array}$ & MAME & $\begin{array}{l}\text { CHEMICAL } \\
\text { TORMULA }\end{array}$ \\
\hline R-11 & Trichlorofluoromethane & $\mathrm{CCl}_{3} \mathrm{~F}$ \\
\hline R.12 & Dichlorodifluoromethane & $\mathrm{CCl}_{2} \mathrm{~F}_{2}$ \\
\hline R-13 & Chlorotrifluoromethane & $\mathrm{CClF}_{3}$ \\
\hline R-13B1 & Bromotrifluoromethane & $\mathrm{CBrF}_{3}$ \\
\hline R-14 & Tetrafuoromethane & $\mathrm{CF}_{+}$ \\
\hline R-21 & Dichlorofluoromethane & $\mathrm{CHCl}_{2} \mathrm{~F}$ \\
\hline R-22 & Chlorodifluoromethane & $\mathrm{CHCIF}_{2}$ \\
\hline R-30 & $\begin{array}{l}\text { Dichloroinethane } \\
\text { (Methylene chloride) }\end{array}$ & $\mathrm{CH}_{2} \mathrm{Cl}_{2}$ \\
\hline R-113 & Trichlorotrifluoroethane & $\mathrm{CCl}_{2} \mathrm{FCClF}_{2}$ \\
\hline R.114 & Dichlorotetrafluoroethane & $\mathrm{CClF}_{2} \mathrm{CClF}_{2}$ \\
\hline $\mathbf{R}-115$ & Chloropentafluoroethane & $\mathrm{CClF}_{2} \mathrm{CF}_{3}$ \\
\hline R-C318 & Octafluorocyclobutane & $\mathrm{C}_{4} \mathrm{~F}_{8}$ \\
\hline R-500 & $\begin{array}{l}\text { Dichlorodifluoromethane, } \\
73.8 \% \text { and Ethylidene } \\
\text { Fluoride, } 26.2 \%\end{array}$ & $\mathrm{CCl}_{2} \mathrm{~F}_{2} / \mathrm{CH}_{3} \mathrm{CHF}_{2}$ \\
\hline R-502 & $\begin{array}{l}\text { Chlorodifluoromethane, } \\
48.8 \% \text { and Chloropenta- } \\
\text { Guoroethane, } 51.2 \%\end{array}$ & $\mathrm{CHClF}_{2} / \mathrm{CClF}_{2} \mathrm{CF}_{3}$ \\
\hline R-744 & Carbon dioxide & $\mathrm{CO}_{2}$ \\
\hline
\end{tabular}

(b) Group 2. The following refrigerants shall be classified as Group 2 refrigerants: 


\begin{tabular}{|c|c|c|}
\hline $\begin{array}{l}\text { OEFIIGERANT } \\
\text { DESIGMATIOH }\end{array}$ & MAME & $\begin{array}{l}\text { CHEMICAL } \\
\text { FORMULU }\end{array}$ \\
\hline $\begin{array}{l}R-40 \\
R-611 \\
R-717 \\
R-764\end{array}$ & $\begin{array}{l}\text { Methyl chloride } \\
\text { Methyl formate } \\
\text { Ammonia } \\
\text { Sulphur dioxide }\end{array}$ & $\begin{array}{l}\mathrm{CH}_{3} \mathrm{Cl} \\
\mathrm{HCOOCH}_{3} \\
\mathrm{NH}_{3} \\
\mathrm{SO}_{2}\end{array}$ \\
\hline
\end{tabular}

\section{Ceneral}

Sec. 1504. Supports for compressors and condensing units shall be designed to safely carry the load of the equipment supported. Supports from buildings or parts of buildings that are of noncombustible construction shall be noncombustible.

Every compressor or portion of a condensing unit supported from the ground shall rest on a concrete slab extending not less than 3 inches above the adjoining ground level.

An unobstructed access opening and passageway, not less than 24 inches in the least dimension, shall be provided and maintained to every compressor, unless otherwise specified by this Code.

A suitable and substantial metal guard shall be provided around all flywheels, fans, pulleys, and belts which are a portion of any tefrigerating machinery.

Refrigerating systems and portions thereof shall not be located in any elevator shaft, dumbwaiter shaft, or any shaft having moving objects therein, nor in any location where it will be subject to mechanical damage.

Every room or space, other than a machinery room complying with the requirements of this Chapter, in which any refrigerant-containing portion of a condensing unit is located, shall be provided with one of the following means of ventilation:

1. Permanent gravity ventilation openings of not less than 2 square feet total area, opening directly to the outside of the building, or extending to the outside of the building by continuous ducts.

2. A mechanical exhaust system of ventilation arranged to provide a complete change of air in such room or space at least every 20 minutes and to discharge to the outer air.

EXCEPTION: This paragraph shall not apply to any portion of a condensing unit in a room or space if the cubical content exceeds 1000 cubic feet per horsepower of the unit or where such room or space has permanent gravity ventilation openings of 2 square feet minimum total area to other rooms or spaces exceeding 1000 cubic feet per hor sepower.

Refrigerant compressors of more than one horsepower rating shall be located not less than 10 feet from any exit in any Group A, B, Division 2, E, I or R, Division I Occupancy unless separated by a One-hour Fireresistive Occupancy Separation.

All refrigerant machinery piping and fittings, brine piping and fittings which during normal operation could reach a surface temperature below 
the dew point of the surrounding air and are located in spaces or areas where condensation could cause a safety hazard to the building occupants. structure, electrical equipment, or any other equipment, shall be protected in a manner to prevent such damage.

Compressors shall not be placed in any hazardous location.

\section{Group 1 Refrigerants}

Sec. 1505. (a) General. Every condensing unit or combination of refrigerant interconnected condensing units totaling 100 or more horsepower rating which contain any Group I refrigerant shall be enclosed in a machinery room. A system containing more than the quantity of a Group T refrigerant allowed in Section ISOS (b) shall be of the indirect type.

EXCEPTION: The requirements of this Section shall not apply to: 1 . Any condensing unit located outside of a building or on the roof of a building and not less than 20 feet from any door, window, or ventilating air opening in any building.

2. Any condensing unit located in a building used exclusively for ice mak. ing or cold storage together with the usual accessory rooms in connection therewith.

3. A Group B, Division 2 or 4 Occupancy, if the quantity of refrigerant does not exceed 30 pounds for each 1000 cubic feel of space in the room in which the condensing unit is localed.

(b) Direct Systems. The maximum quantity of a Group I refrigerant in a direct system in all occupancies other than Group I shall not exceed that set forth in Table No. 15-A.

Direct Systems in Group I Occupancies shall be limited to systems each containing not more than 50 percent of the permissible quantities of Group 1 refrigerants set forth in Table No. 15-A. When the refrigerantcontaining parts of a system are located in one or more enclosed spaces, the cubical content of the smallest enclosed humanly occupied space other than the room in which the refrigeration equipment is located, shall be used to determine the permissible quantity of refrigerant in the system. Where a refrigerating system has evaporator coils serving individual stories of a building, the story having the smalles! volume shall be used 10 determine the maximum quantity of refrigerant in the entire system.

When the evaporator is located in an air duct system, the cubical content of the smallest humanly occupied enclosed space served by the air duct system shall be used to determine the permissible quantity of refrigerant in the system.

EXCEPTION: If the air flow to any enclosed space served by a portion of an air duct system cannol be shul off or reduced below one-quarter of its maximum, the cubical contents of the entire space served by that portion of the air duct system may be used to determine the permissible quantity of

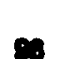
refrigerant in the system. 
TABLE.NO. 15-A-MAXIMUM PERMISSIBLE QUANTITIES OF GROUP 1 REFRIGERANT FOR DIRECT SYSTEMS

\begin{tabular}{|c|c|c|}
\hline $\begin{array}{l}\text { REFRIGERAMT } \\
\text { DESIGMATION }\end{array}$ & MAME & $\begin{array}{l}\text { MuXImuM aUANTIT } \\
\text { IH LB. PER } 1000 \\
\text { CU. } 7 \text {. OF HUMANLY } \\
\text { OCCUPIEO SPACE }\end{array}$ \\
\hline $\begin{array}{l}R-11 \\
R-12 \\
R-13 \\
R-13 B 1 \\
R=14 \\
R-21 \\
R-22 \\
R-30\end{array}$ & $\begin{array}{l}\text { Trichlorofluoromethane } \\
\text { Dichlorodifluoromethane } \\
\text { Chlorotrifluoromethane } \\
\text { Bromotrifluoromethane } \\
\text { Tetrafuoromethane } \\
\text { Dichlorofluoromethane } \\
\text { Chlorodifluoromethane } \\
\text { Dichloromethane }\end{array}$ & $\begin{array}{r}35 \\
31 \\
27 \\
38 \\
23 \\
13 \\
22 \\
6\end{array}$ \\
\hline $\begin{array}{l}R-113 \\
R-114 \\
R-115 \\
R-C 318 \\
R-500\end{array}$ & $\begin{array}{l}\text { Trichlorotrifuoroethane } \\
\text { Dichlorotetrafluoroethane } \\
\text { Chloropentafluoroethane } \\
\text { Octafluorocyclobutane } \\
\text { Dichlorodifuoromethane, } \\
73.8 \% \text { and Ethylidene }\end{array}$ & $\begin{array}{l}24 \\
44 \\
40 \\
50 \\
26\end{array}$ \\
\hline R.502 & $\begin{array}{l}\text { Chlorodifiuoromethane, } \\
48.8 \% \text { and Chloropenta- } \\
\text { fluoroethane, } 51.2 \%\end{array}$ & 30 \\
\hline R-744 & Carhon dioxide & 11 \\
\hline
\end{tabular}

\section{Group 2 Refrigerants}

Sec. 1506. A mechanical refrigerating system or unit refrigerating system containing a Group 2 refrigerant shall not be located within a building unless all refrigerant-containing portions of the system are enclosed in a machinery room. Such systems when installed outside of a building shall be located at least 20 feet from any exit, door, window, or ventilating air inlet in any building.

EXCEPTION: This shall not apply to a building used exclusively for ice making, cold storage, or for the manufacluring or processing of food or drink, provided the occupant load does not exceed one person per 100 square feel of floor area served by such system.

Portions of refrigerating systems containing Group 2 refrigerants shall not be located in an exit.

\section{Machinery Rooms}

Sec. 1507. Required machinery rooms shall be of at least one-hour fireresistive construction with all interior openings protected with fire assemblies having a one-hour fire protection rating. Doors shall be self closing.

There shall be no direct opening between any machinery room containing any Group 2 refrigerant and any room or space in which there is an open flame, spark-producing device, or heating surface in excess of $800^{\circ} \mathrm{F}$. Every machinery room containing any Group 2 refrigerant shall 
have at least two means of exit located at least one-fifth the perimeter of the room apart. Exit openings shall be not less than 3 feet by 6 feet 8 inches.

Every machinery room containing any Group I refrigerant shall have at least one means of exit. Such exit opening shall be not less than 3 feet by 6 feet 8 inches.

Every machinery room door shall open in the direction of egress.

Every machinery room shall have an area of not less than 50 square feet.

An unobstructed working space not less than 2 feet 6 inches in width and not less than 7 feet in height shall be provided around not less than two adjacent sides of all moving machinery in any machinery room.

\section{Machinery Room Ventilation}

Sec. 1508. Every machinery room shall be provided with means of ventilation to the outer air. Such ventilation shall be cither:

1. An exhaust system of ventilation arranged to provide a complete change of air in such room at least once every five minutes and discharge to the outer air at a location not less than 20 feet from any exterior door, window or ventilation air inlet in any building.

Each exhaust ventilation system shall be controlled by a readily accessible emergency ventilation switch located within 2 feet of the switch specified in Section 1509 and the switch shall be labeled to comply with Section 1519, or

2. Gravity ventilation openings 10 the outside of the building having a cross-sectional area of one-twentieth of the noor area of the machinery room, bút in no case need the area of the openings be more than 1000 square inches. Such openings shall be so installed that approximately one. half of the required area is located within 12 inches of the ceiling and one-half of the required area is located within 12 inches of the floor of the room. Every portion of the lower opening shall be horizontal or slope downward from the opening in the machinery room to the exterior of the building at or above the adjacent ground level.

\section{Equipment In a Machinery Room}

Sec. 1509. Combustion air shall not be taken from a machinery room. [See Section 603 (c).]

Electrical equipment or electrical control or control panel other than listed below shall not be located in any machinery room:

1. Lights and receptacles.

2. Machinery room exhaust fans and blowers.

3. Any refrigerating condensing unit or portion thereof.

4. Circulating pumps for condensers, cooling towers, or cooling coils.

S. Air compressors serving only automatic controls within the refrigerating or cooling system.

6. Electrically operated valves for the control of a refrigerant or for the control of the circulation of a cooling fluid. 
7. Blowers and fans for cooling towers or for condensers.

8. Any electric control or control panel for any of the above items.

A readily accessible single emergency refrigeration control switch shall be provided to shut off all electrically operated machinery in any machinery room, except the exhaust ventilation system complying with Section 1508. Such switch shall be controlled from a point outside of, and within 10 feet of the required opening to the machinery room it serves, and the switch shall be labeled to comply with Section 1519. For other requirements concerning the location of this switch, see the Electrical Code.

\section{Refrigerant Piping, Containers, and Valves}

Sec. 1510. All materials used in the construction and installation of refrigerating systems shall be suitable for the refrigerant in the system, and no material or equipment shall be installed which will deteriorate due to the chemical action of the refrigerant or the oil, or combination of both.

All copper and brass refrigerant piping valves, fittings, and related parts used in the construction and installation of refrigerating systems shall be approved for such use. (See Refrigeration Piping in Equipment Standards, Appendix of this Code.)

All iron and steel refrigerant piping shall comply with the requirements of U.M.C. Standard No. 15-1. Pipe more than 2 inches iron pipe size shall be electric resistance welded, or seamless pipe.

Pipe subject to working pressure in excess of 300 pounds per square inch shall have a minimum wall thickness of not less than that specified in U.M.C. Standard No. 15-1; Table No. 15-1-A for Schedule 80 pipe.

Iron or steel refrigerant piping $11 / 2$-inch nominal size and smaller and containing liquid refrigerant shall have a minimum wall thickness of not less than that specified in U.M.C. Standard No. 15-1; Table No. 15-1-A for Schedule 80 pipe, or Schedule $\mathbf{4 0}$ pipe if all field joints are welded.

Brass pipe, copper pipe and copper tubing shall conform to the requirements of U.M.C. Standard No. 15-2. Brass pipe and copper pipe subject to working pressures in excess of 250 pounds per square inch shall be not less than extra strong pipe. Copper water tubing used for refrigerant piping shall be not less than type $K$ or $L$ and strat be free from scale and dirt.

Soft annealed copper tubing regulated by this Section shall be not largek than 1 3/8-inch nominal size. No mechanical joint shall be made on any material larger than $1 / 4$-inch nominal size.

Soft annealed copper tubing conveying any refrigerant shall be enclosed in iron or steel piping and fittings or in conduit, molding, or raceway which will properly protect such tubing against mechanical injury from an exterior source.

EXCEPTION: The requirements of this Section shall not apply to:

1. Tubing entirely within a refrigerator or tubing within 5 feet of a refrigerant compressor where so located that it is not subject to external injury. 
2. Tubing serving a dwelling unit, when such tubing contains Group 1 refngerant and is placed in locations not subject to damage from an external source.

\section{Erection of Refrigerant Piping}

Sec. 1511. Piping and tubing shall be installed so as to prevent excessive vibration and strains at joints and connections.

All piping and tubing shall be securely fastened to a permanent support within 6 feet following the first bend in such tubing from the compressor, and within 2 feet of every other bend or angle. In every case, piping and tubing shall be supported al points not more than 15 feet apart.

Refrigerant piping crossing an open passageway in any building shall be not less than $7 \frac{1}{2}$ feet above the noor unless against the ceiling of such space.

All refrigerant piping and tubing shall be installed so that it is not sub. ject to damage from an external source.

Refrigerant piping and joints connected and installed in the field shall be exposed to view for visual inspection and accepted by the Building Official prior to being covered or enclosed.

EXCEPTION: This shall nol apply to sofi annealed copper tubing enclosed in iron or steel piping conduit, molding, or raceway provided there are no filtings or joints concealed therein.

Copper tubing containing other than a Group I refrigerant shall not be located in a public hallway, lobby, or stairway of any building unless enclosed in iron or steel piping and fittings or in metal rigid conduit.

EXCEPTION: This Section shall not apply to hard-drawn copper tubing installed in locations where not subjecl to injury from an external source.

All iron or steel refrigerant piping placed underground shall be coated with sufficient asphalt paint or equal to inhibit corrosion.

Iron or steel pipe joints shall be screwed, flanged, or welded. Screw joints shall be of an approved type. (See Pipe Threads in Equipment Standards, Appendix of this Code.) Exposed threads shall be tinned or otherwise coated to inhibit corrosion.

Welds shall be of an approved lype. (See Refrigeration Piping in Equipment Standards, Appendix of this Code.)

Copper or brass pipe of iron pipe size shall be screwed, flanged, or brazed.

Every tubing joint and connection shall be a flared, lapped, or swaged brazed joint.

EXCEPTION: Soldered joints may be used to connect any valve located outside of an air conditioning duct or plenum to adjoining tubing in any refrigerating system containing Group 1 refrigerant other than carbon dioxide.

\section{Aofrigerant Containers}

Sec. 1512. Every refrigerant container or evaporator which is not a part of listed equipment, shall be constructed in accordance with approved standards. 


\section{Refrigerant Control Valves}

Sec. 1513. A stop valve shall be installed in the refrigerant piping of every refrigerating system at the following locations:

1. At each inlet and outlet of every positive displacement type compressor.

2. At each refrigerant outlet of every receiver.

3. At each refrigerant inlet of every pressure vessel containing liquid refrigerant and having an internal gross volume exceeding 3 cubic feet, which vessel is a portion of a refrigerating system equipped with a positive displacement type of compressor.

Stop valves installed in refrigerant lines composed of copper tubing $3 / 4$ inch or less outside diameter, shall be securely supported independent of the tubing or piping connected to such valve.

\section{Pressure Limiting Device}

Sec. 1514. A pressure limiting device shall be installed on every positive displacement refrigerant compressor which is a portion of:

1. Any refrigerating system containing Group 2 refrigerant.

2. Any air cooled refrigerating system containing Group 1 refrigerant of 10 horsepower or more rating.

3. Any water cooled refrigerating system containing Group 1 refrigerant of three horsepower or more rating.

Every pressure limiting device shall stop the action of the compressor it serves at a pressure not in excess of 90 percent of the pressure set forth in Table No. 15-B for the kind of refrigerant contained in such refrigerating system.

A stop or shut-off valve shall not be placed between any pressure limiting device required by this Section and the compressor it serves.

\section{Pressure Relief Valves-Compressors}

Sec. 1515. The following compressors of the positive displacement type shall be equipped with a relief valve:

1. Every Group 1 refrigerant compressor of 20 or more horsepower rating which is a portion of any refrigerating system operating at a pressure in excess of 15 pounds per square inch in the high pressure side of the system.

2. Every compressor which is a portion of any refrigerating system containing any Group 2 refrigerant.

EXCEPTION: The requirements of this Section shall not apply to a com. pressor listed without such relief valve.

Every pressure relief valve shall be connected to the refrigerant discharge side of the compressor it serves, between such compressor and any stop valve.

Every pressure relief valve required by this Section shall discharge into the low pressure side of the refrigerating system it serves or discharge to the outside of the building as required by this Code. Any pressure relief 
device that discnarges from the high pressure side of the refrigerating system into the low pressure side must be of a type that is not appreciably affected by back pressure.

Every pressure relief valve required by this Section shall be set to function at a pressure not in excess of the pressure set forth in Table No. 15-B corresponding to the portion of the refrigerating system in which such valve is located and the kind of refrigerant contained in such system.

A stop or shutoff valve shall not be installed between any pressure relief valve recuired by this Section and the compressor it serves.

\section{Pressure Reliel Devices - Pressure Vessels}

Sec. 1516. Every pressure vessel over 6 inches in diameter which may be shut off by valves from other parts of the system shall be equipped with a pressure relief device or devices complying with requirements of this Code.

Pressure vessels of 3 cubic feet or less gross volume containing liquid refrigerant shall be equipped with either a pressure relief valve, fusible plug, or rupture member, provided, however, that a fusible plug is permitted only on the high pressure side of the refrigerating system.

Pressure vessels having a gross volume of more than 3 cubic feet shall be equipped with a pressure relief valve or rupture member.

\section{Pressure Reliet Device Requirements}

Sec. 1517. Except as provided in this Section, every pressure relief device for any refrigerant vessel shall be set 10 function at a pressure not exceeding that set forth in Table No. 15-B for the portion of the system to which the device is connected and for the refrigerant in such container.

Pressure relief devices may be set to start to function at a pressure not to exceed the design working pressure of the pressure vessel as determined by the manufacturer and stamped on the pressure vessel.

\section{WHERE}

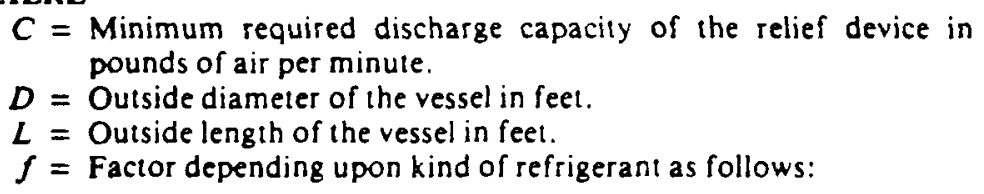

\section{Kind of Refrigerant}

Ammonia

$R-12, R-22$, and $R-500$

R-502

All other refrigerants

\section{Value of $f$}

0.5

1.6

2.2

1.0

The size of the discharge pipe from the pressure relief device shall be not less than the size of the relief device outlet. The discharge from more than one relief device may be run into a common header, the area of which shall be not less than the sum of the area of the pipes connected thereto. 
TABLE NO. 15-B - PRESSURES FOR UNLISTED EQUIPMENT

\begin{tabular}{|c|c|c|c|}
\hline \multirow[b]{2}{*}{ MEFRIGERAMT } & \multirow{2}{*}{ 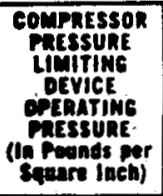 } & \multicolumn{2}{|c|}{ 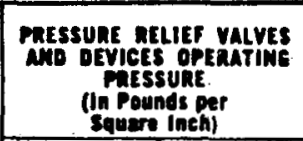 } \\
\hline & & $\begin{array}{c}\text { Wight pressurs } \\
\text { side }\end{array}$ & $\begin{array}{l}\text { Low Pressure } \\
\text { side. }\end{array}$ \\
\hline Ammonia & 225 & 250 & 150 \\
\hline Carbon Dioxide & 1200 & 1350 & 1000 \\
\hline Dichloroethylene & 5 & 10 & 10 \\
\hline $\begin{array}{l}\text { Dichloromethare } \\
\text { (Refrigerant 1) }\end{array}$ & 25 & 30 & 30 \\
\hline Ethyl Chloride & $=\mathbf{5 0}$ & 55 & 50 \\
\hline Trichloroethylene & 25 & 30 & 30 \\
\hline $\begin{array}{l}\text { Trichloromonofluoromethane } \\
\text { (Refrigerant 11) }\end{array}$ & 25 & 30 & 30 \\
\hline $\begin{array}{l}\text { Dichlorodifluoromethane } \\
\text { (Refrigerant 12) }\end{array}$ & 160 & 225 & 125 \\
\hline $\begin{array}{l}\text { Dichloromonofluoromethane } \\
\text { (Refrigerant 21) }\end{array}$ & 60 & 70 & 50 \\
\hline $\begin{array}{l}\text { Monochlorodifluoromethane } \\
\text { (Refrigerant 22) }\end{array}$ & 245 & 300 & 245 \\
\hline $\begin{array}{l}\text { Trichlorotrifluoroethane } \\
\text { (Refrigerant 113) }\end{array}$ & 25 & 30 & 30 \\
\hline $\begin{array}{l}\text { Dichlorotetrafluoroethane } \\
\text { (Refrigerant 114) }\end{array}$ & 45 & 50 & 50 \\
\hline Methyl Chloride & 170 & 200 & 125 \\
\hline Methyl Formate & 25 & 30 & 30 \\
\hline Sulphur Dioxide & 125 & 150 & 85 \\
\hline Refrigerant 500 & 160 & 225 & 125 \\
\hline Refrigerant 502 & 245 & 300 & 150 \\
\hline
\end{tabular}


Whenever the length of the discharge piping exceeds 50 feet, such piping shall be increased one pipe size in diameter.

All piping and fittings used for any relief device discharge piping system shall conform to this Code.

Every pressure relief device shall bear thereon:

1. Name or trademark of the manufacturer of such device.

2. The discharge or bursting pressure selting of such device expressed in pounds per square inch gage.

3. The minimum diameter of the discharge outlet or opening of such valve.

4. The discharge capacily of the pressure relief device in pounds of air per minute.

Every pressure relief valve shall be set and sealed by the manufacturer of such valve or any such valve may be set and sealed in a laboratory approved by the Building Official, provided such valve is properly relabeled.

Every pressure relief device required by this Section for any pressure vessel of 3 cubic feet gross volume or more containing Group 1 refrigerant or any pressure vessel containing any Group 2 refrigerant shall discharge to the atmosphere at a location not less than 15 feet above the adjoining ground level and not less than 20 feet from any window, ventilation opening, or exit in any building.

Every pressure relief device required by this Section shall be connected as close as practicable to the refrigerant container or evaporator it serves and above the refrigerant level in such container or evaporator.

A stop or shutoff valve shall not be placed between any pressure relief device required by this Section and the pressure vessel it serves.

\section{Manual Discharge of Refrigerant}

Sec. 1518. (a) Discharge to Atmosphere. Every refrigerating system located in a building and containing carbon dioxide or a Group 2 refrigerant shall be equipped with means for manual discharge of the refrigerant to the atmosphere. Such discharge system shall comply with all of the following requirements:

1. A discharge pipe shall be provided above the liquid refrigerant level from both the high and low pressure side of the system and the pipes shall extend into an emergency refrigerant control box complying with this Section. Each discharge pipe shall have a minimum nominal diameter of 1 inch.

2. A readily accessible stop valve and a high pressure gage shall be installed on each discharge pipe within the emergency refrigerant control box. The gage shall be located ahead of each stop valve and the valves shall have the same capacity as the discharge pipe it serves. A permanent label shall be attached to each valve reading: "Discharge Valve to At- 
mosphere" and shall indicate the side of the system to which it is connected.

3. Each discharge pipe shall extend from the discharge side of the valve to a common pipe having a nominal diameter of 1 inch. This common pipe shall terminate outside the building, not less than 6 feet above the highest structure on the building and not less than 20 feet from any window, ven. tilation opening, or exit, of any building. The outlet opening shall be capped with a low pressure rupturable diaphragm, such as a heavy foil disk in a pair of flanges, or equivalent.

4. A stop valve, which could prevent manual discharge of the refrigerant to the atmosphere, shall not be located between the emergency refrigerant discharge valves and the side of the system they are serving.

(b) Release from High Pressure Side. Every refrigerating system required to have means of manual discharge of its refrigerant to the atmosphere also shall be equipped with manual means of releasing the refrigerant from the high pressure side of the system to the low pressure side. This manual means shall comply with all of the following re. quirements:

1. The high and low pressure side of the system shall be interconnected with a pipe having a minimum nominal diameter of $1 \mathrm{inch}$. This interconnection shall be made above the liquid refrigerant level.

2. A readily accessible manual stop valve shall be installed in this interconnecting pipe, and the valve shall be located within the emergency refrigerant control box. This valve shall have the same capacity as the pipe connected thereto.

3. A permanent label shall be attached to this valve reading: "High to Low Pressure Control Valve."

4. A stop valve, which could prevent releasing of the refrigerant from the high pressure side of the system to the low pressure side, shall not be installed in this interconnecting pipe between the high and low pressure side of the system.

(c) Emergency Refrigerant Control Box. Every emergency refrigeran control box shall be located outside of the building on a street front or shall be equally accessible and shall be not more than 6 feet above the sidewalk or adjoining ground level. This box shall be of iron or steel not less than No. 16 gage thickness and provided with a hinge cover and lock. Such box shall be provided with a permanent label on the outside cover reading: "Emergency Refrigerant Control Box" and the name of the refrigerant in the system.

All piping, valves, fittings, and related parts, required to be installed to comply with this Section, shall conform to Section 1510 of this Code.

\section{Labels}

Sec. 1519. In addition to labels required elsewhere in this Code, every 
refrigerating system shall be provided with labels complying with the requirements of this Section.

Every condenser, receiver, absorber, accumulator and similar equipment of more than 3 cubic feet gross volume and containing any Group 2 refrigerant shall be equipped with a permanent label setting forth the type of refrigerant in such vessel. Every vessel having a gross volume of more than 10 cubic feet and containing any Group 1 refrigerant shall be equip. ped with a permanent label setting forth the type of refrigerant in such vessel.

Every manifold or distributing panel shall have a permanent label setting forth the refrigerating equipment controlled by each valve on such panel.

All exposed refrigerant piping shall be labeled at intervals of not more than 30 feet apart plus a label in every area through which the piping extends specifying the refrigerant in such piping.

EXCEPTION: The provisions of this Section shall not apply 10:

1. Piping in brine tanks.

2. Piping in that portion of any building used exclusively for ice making, cold storage, or for the processing of any material by means of refrigeration.

Every refrigerating system, which is required to be located in a machinery room, shall be equipped with permanent labels having letters not less than $1 / 2$ inch in height designating the following equipment:

1. The main power disconnect switch for such refrigerating system.

2. Every remote control device for any such main power switch.

3. The main shutoff valve for each liquid refrigerant container.

4. Every pressure limiting device and pressure relief device located out. side the room or space in which the refrigerant container it serves is located.

Every exhaust ventilation system control switch required to be installed to comply with Section 1508 shall have a permanent label reading: "Emergency Refrigeration Switch."

Every control switch provided to shut off all electrically operated machinery in a machinery room, as required by Section 1509, shall have a permanent label reading: "Emergency Refrigeration Switch."

In every refrigeration machinery room and for every direct refrigerating system of more than 10 horsepower there shall be placed a permanent sign within 10 feet of the compressor giving the following information:

1. Name of contractor installing equipment.

2. Kind of refrigerant in system.

3. Amount of refrigerant in system.

Every pressure relief device required by this Code shall be labeled to comply with Section 1517.

\section{Testing of Rofingerating Equipment}

Sec. 1520 . All refrigerant-containing portions of every field assembled 
refrigerating system intended or installed to operate at a pressure in excess of atmospheric pressure shall be subjected to a test pressure of nol less than the pressure set forth in Table No. 15-C for the kind of refrigerant in such system.

Pressure tests required by this Section shall not be less than the lowest setting of any pressure relief device installed in the side of the system it is protecting.

The requirements of this Section shall not apply to:

1. Any refrigerating system containing 20 pounds or less of Group I refrigerant.

2. Safety devices, pressure gages, compressors, and control mechanisms which have been factory tested.

3. Pressure vessels constructed in accordance with approved standards.

The test pressure applied to any refrigerant container shall not exceed two and one-half times the design working pressure stamped on such con. tainer.

The high pressure test for any refrigerating system intended to contain any refrigerant not listed in Table No. 15-B shall be not less than the saturated vapor pressure of such refrigerant at a temperature of $150^{\circ} \mathrm{F}$. In no case shall the test pressure be less than 30 pounds.

Every refrigerating system installed to operate at a pressure below atmospheric pressure shall be required to maintain a partial vacuum in the system equal to the pressure of a column of mercury not less than 20 inches in height.

Every refrigerating system shall sustain the test pressure specified in this Section for a period of not less than 10 minutes after the pressure imposing equipment has been cut off or disconnected.

Every pressure test for those portions of any refrigerating system to contain ammonia or carbon dioxide shall be made with air or dry gas.

Refrigerating systems shall not be tested with oxygen.

Brine piping may be tested with air, water, or dry gas.

All brine piping which is a portion of any refrigerating system shall be tested to a pressure of not less than 100 psi for a period of 10 minutes.

Additional tests of any refrigerating system may be demanded by the Building Official when deemed necessary to insure the safety of such system.

Every test required by this Section shall be conducted by the owner or contractor in the presence of the Building Official. 
TABLE NO. 15-C_FIELD LEAK TEST PRESSURES IN PSI

\begin{tabular}{|c|c|c|}
\hline metrieerant & misn paessune & LOW mEEsURE \\
\hline Ammonia & 300 & 150 \\
\hline Carbon Dioxide & 1500 & 1000 \\
\hline Dichlorcethylene & 30 & 30 \\
\hline Dichloromethane (Refrigerant 1) & 30 & 30 \\
\hline Ethyl Chloride & 60 & 50 \\
\hline Trichloroethylene & 30 & 30 \\
\hline $\begin{array}{l}\text { Trichloromonofluoromethane } \\
\text { (Refrigerant 11) }\end{array}$ & 30 & 30 \\
\hline $\begin{array}{l}\text { Dichlorodifluoromethane } \\
\text { (Refrigerant 12) }\end{array}$ & 235 & 140 \\
\hline $\begin{array}{l}\text { Dichloromonoluoromethane } \\
\text { (Refrigerant 21) }\end{array}$ & 70 & 40 \\
\hline $\begin{array}{l}\text { Monochlorodifluoromethane } \\
\text { (Refrigerant 22) }\end{array}$ & 300 & 150 \\
\hline $\begin{array}{c}\text { Trichlorotrifuoroethane } \\
\text { (Refrigerant 113) }\end{array}$ & 30 & 30 \\
\hline $\begin{array}{l}\text { Dichlorotetrafluoroethane } \\
\text { (Refrigerant 114) }\end{array}$ & 50 & 50 \\
\hline Methyl Chloride & 210 & 120 \\
\hline Methyl Formate & 50 & 50 \\
\hline Sulphur Dioxide & 170 & 85 \\
\hline Refrigerant 500 & 225 & 125 \\
\hline Refrigerant 502 & 300 & 150 \\
\hline
\end{tabular}


$$
.
$$ 


\section{APPENDIX P-6}

\section{PLUMB ING}

\section{Chapter 9 \\ HANGERS AND SUPPORTS}

\section{Strosees and Straln}

Sec. 901 . Piping in a plumbing system shall be installed so as to prevent arains and stresses which will exceed the structural strength of the pipe. Provision shall be made for expansion and contraction of the piping.

\section{Matorial}

Sec. 902. Hangers, anchors and supports shall be of metal, plastic or other approved material of sufficient strength to support the piping and its contents. Piers may be of concrete, brick or other approved material.

\section{Attachment to Bullding}

Sac. 903. Hangers and anchors shall be securely attached to the building construction at sufficiently close intervals to suppon the piping and its cotents.

\section{Plastle Plpo Supports}

Sec. 904. Hangers and straps shall not compress, distort, cut or abrade the piping and shall allow free movement of the pipe. Approved restraint fittings and expansion joints shall be installed in accordance with their approva. Support all pipe at intervals of not more than 4 feet at end of branches and at change of direction or elevation. Supports shall allow free movement. Maintain vertical piping in straight alignment. Support trap erms in excess of 3 feet as close as possible to the trap. Installations shall be in accordance with approved methods.

\section{Epacing}

Cec. 905. Pipe shall be supported at distances not to exceed those indicated in Table No. 9-A.

\section{Underoround installation}

8ex. 907 . The trench bottom shall be smooth and of uniform grade with either undisturbed ground or a layer of selected and compacted backfill so that no settlement will be encountered. Pipe must bear on this material throughout its entire length.

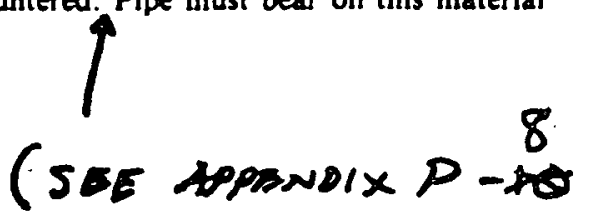

TABLE NO. QA

\begin{tabular}{|c|c|c|}
\hline PEE BATERLAL & 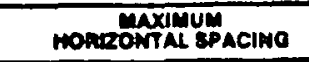 & VERTICAL BPACINO \\
\hline Cast Iron Soil Pipe & $\begin{array}{l}5^{\prime}, 0^{\prime \prime} \text { except may be } \\
10^{\prime}-0^{\circ} \text { where } 10^{\prime} \\
\text { lengths of pipe are } \\
\text { installed }\end{array}$ & Base and each story height \\
\hline Threaded Steel Pipe & $\begin{array}{l}1^{\circ} \text { diameter and } \\
\text { under }-8^{\prime}-0^{\prime \prime} \\
1 y^{\circ} \text { diameter and } \\
\text { over }-10^{\prime}-0^{\circ}\end{array}$ & Every other story height \\
\hline Copper Tube & $\begin{array}{l}1 \%^{\prime \prime} \text { diameter and } \\
\text { under }-6^{\prime}-0^{*} \\
1 \%^{\prime \prime} \text { diameter and over- } \\
10^{\prime}-0^{\circ}\end{array}$ & $\begin{array}{l}\text { Each story height but not to } \\
\text { eaceed } 10^{\prime}-0^{\circ}\end{array}$ \\
\hline Lead Pipe & Continuous support & $4^{\prime}-0^{\prime \prime}$ \\
\hline Plastic Pipe' & $4^{\prime}-0^{\prime \prime}$ & $4^{\prime}-0^{\prime \prime}$ \\
\hline
\end{tabular}

For edditiond support requirements for plautic pipe, see Section 904. 
$\theta$

0 


\section{Chapter 10}

\section{TESTS}

\section{Concealmont Prohlbited}

Sec. 1001. All new, altered, extended or replaced plumbing shall be left uncovered and unconcealed until it has been tested and approved. Where auch work has been covered or concealed before it is tested and approved, in shall be exposed for testing.

\section{Equipmont, Material and Labor}

Sec. 1002. All equipment, material and labor required for testing a plumbing system or part thereof shall be furnished by the permit holder or the individual requesting inspection.

\section{Required}

Sex. 1003. New plumbing systems and parts of existing systems which have been altered, extended or repaired shall be tested as prescribed bereinafter in the presence of the building official to disclose leaks and defects, except that testing may be wajved in the following cases:

EXCEPTIONS: 1. In any case which does not include addition to, replacement, alteration or relocation of any water supply, drainage of vent piping: and

2. In any case where plurabing equipment may be set up temporarily for exhibition purposes.

\section{Water-supply Systoms}

Sec. 1006. Upon completion of a section or of the entire water-supply system, it shall be tested and proved tight under a water pressure not less than the working pressure under which it is to be used. The water used for tests shall be obrained from a potable source of supply. Except for plastic pipe systems, the water test may be substituted by an air test of 50 pounds per square inch. Test pressures shall be maintained for a minimum period of 15 minutes without the system leaking. 
$$
.
$$ 


\section{APPENDIX P-8 \\ PLUMB ING}

\section{Tranching, Bodding, Tunnoling and Backfllling}

Sec. 811. (a) Treaching and Bedding. Trenches shall be sufficient width to permit proper installation of the pipe. Where shoring is required, ample allowance shall be made in trench width for proper working conditions. Where trenches are excavated to a depth such that the bottom of the trench forms the bed for the pipe, care must be exercised to provide solid and continuous bearing between joints, and bell holes shall be provided at points where the pipe is joined. Where trenches are excavated to a depth ach that the bottom of the trench does not form the bed for the pipe, the trench shall be backfilled to grade with sand or fine gravel placed in layers of six inches maximum depth and compacted after each placement. The pipe shall not be supported on blocks to grade. Where rock is encountered in trenching, it shall be removed to a point at least three inches below the grade line of the trench and the trench shall be backfilled to grade with and tamped in place so as to provide uniform bearing for the pipe between joints. Care shall be exercised to see that the pipe does not rest on rock at any point including the joints. If soft materials of poor bearing qualitites are found at the bottom of the trench, stabilization shall be chieved by overexcavating at least two pipe diameters and bringing up to prade with fine gravel or crushed stone or a concrete foundation. Such concrete foundation shall be bedded with sand tamped in place so as to provide a uniform bearing for the pipe between joints.

(b) Traseling. Where necessary, pipe may be installed by tunneling or jacking, or a combination of both. In such cases, special care shall be exercised to protect the pipe from damage either during installation or from absequent uneven loading. Where earth tunnels are used, adequate supporting structures shall be provided to prevent future settling or caving. Pipe may be installed in larger conduit which has been jacked through unexcavated portions of the trench.

(c) Baclariling. Until the crown of the pipe is covered by at least two feet of tamped earth considerable care shall be exercised in backfilling trenches. Loose earth, free of rocks, broken concrete, frozen chunks and other nubble, shall be carefully placed in the trench in six-inch layers and tamped in place. Care shall be taken to thoroughly compact the backfill under and beside the pipe to be sure that the pipe is properly supporied. Backfill shall be placed evenly on both sides of the pipe and tumped in such manner as to retain proper alignment.

\section{4}

\section{Protectlon of pipess}

Eec. 816. (a) Dreakage. Pipes passing under or through walls shall be protected from breakage. Any plumbing pipe passing under a footing or through a foundation wall shall be provided with a relieving arch, or there 
thall be built into the masonry wall an iron-pipe sleeve two pipe sizes creater than the pipe passing through, or equivalent protection shall be provided as may be approved in writing by the building official.

(b) Corrodon. Pipe and fittings subject to corrosion by passing through or under corrosive fill such as, but not limited to, cinders, concrete or other corrosive material shall be protected against external corrosion by epproved protective coating, wrapping or other means which will resist auch corrosion.

(c) Stres: Prolecton. All piping within a plumbing system shall be so inatalled that connections or piping will not be subjected to undue stresses or trains. Provisions shall be made for expansion, contraction and structural ettlement.

(d) Maintenance of Structural Integrity-Cutting, Notching, Boring for, and Embedment of Plpes. 1. Gemeral. Structural members shall not be weakened or impaired by boring, notching or cutting. Piping shall not be built into nor embedded in concrete or mesonry except that designated radiant heating or cooling panels may have black steel, wrought iron pipe or Type $L$ copper tubing embedded. Placement of pipes in unfilled cores of bollow unit masonry is not considered embedment. Piping shall pass vertically or horizontally through masonry or concrete walls by means of deeves large enough to pass flanges, hubs, couplings and insulation. Unless otherwise specified, sleeves shall be separated by at least three diameters on center.

In the case of penetrations in other than conventional light frame wood construction, the building of ficial may require plans and specifications to be prepared and designed by an engineer or architect licensed by the state to practice as such.

2. Conventional Uight Frame Wood Construction: Jolsts. In wood

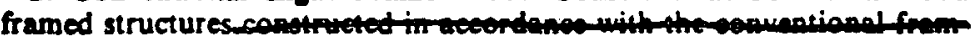

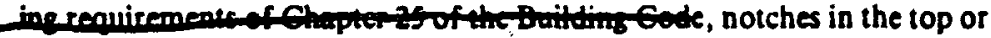
bottom of joists shall not exceed one-sixth the depth of the joist and shall not be located in the middle third of the span. Holes bored in joists shall not be within two inches of the top or bottom of the member; the diameter of holes shall not exceed one-third the joist depth.

Sted Walls and Partitions. In exterior walls and bearing partitions, wood studs may be cut or notched to a depth not exceeding one-fourth their depth. In nonbearing partitions, notches may be 40 percent of the tud depth.

Wood studs may be bored to a diameter not exceeding 40 percent of their depth, provided the hole permits at least $k$ inch of wood remaining to the edge. Bored holes shall not be located at the same section of stud as cut or notch. Bored holes not greater than 60 percent of the width of the tud are permitted in nonbearing partitions or in a wall where each bored and is doubled, and provided not more than two successive doubled studs ere bored. 
Ppes in Walls. Stud partitions containing plumbing shall be so framed and the joists underneath so spaced as to give the proper clearance for the piping. Where partitions containing piping run parallel to the floor joists, the joists under the partition shall be doubled and spaced to permit the passage of pipes. The joists shall be bridged or solidly blocked for lateral apport on both sides of the penetration. If plumbing pipes are placed so a to necessitate cutting a sole or plate, a metal tie not less than $K$ inch thick and $1 \frac{1}{6}$ inches wide shall be fastened to the plate across and to each side of the opening with not less than four $16 \mathrm{~d}$ nails.

\section{Eloeṽes}

Sec. 817. In exterior walls, annular space between sleeves and pipes shall be filled or tightly caulked with material found effective and approved as ach by the building official.

\section{Waterprooflng of Openings}

Eec. 818. Joints at the roof, around vent pipes, shall be made watertight by the use of lead, copper, aluminum, plastic or other approved flashing or flashing material. Exterior wall openings shall be made watertight.

\section{Ratproofing}

Sec. 819. (a) Stralaer Pistes. All strainer plates on drain inlets shall be designed and installed so that no opening is greater than $1 / 2$ inch in least dimension.

(b) Openings. In or on buildings where openings have been made in walls, foors or ceilings for the passage of pipes, they shall be closed and protected by the installation of approved metal collars securely fastened to the adjoining structure or as directed by the building official.

\section{Foodhandling Establishments}

Sec. 820. Food or drink shall not be stored, prepared or displayed beneath overbead sewer or drain pipes unless such pipes are protected egainst leakage or condensation reaching the food or drink as described below for new construction. In newly constructed or remodeled establishments, soil or drain pipes located over food preparation, storage, display or serving areas are undesirable. Whete building design requires that soil or drain pipes be located over such areas, the installation shall be made with the least possible number of joints and shall be installed so as 10 connect to a vertical stack at the nearest wall or vertical building support and the construction shall be performed as follows:

1. All openings through floors over such areas shall be provided with eceves securely bonded to the floor construction and projecting not less then $y_{6}$ inch above top of finished floor with space betwen sleeve and pipe or duct realed.

2. Floor and shower drains installed above such areas shall be equipped with integral seepage pans.

3. Plumbing fuxtures in rooms located above such areas shall be of the will-mounted type, with the exception of bath tubs. Tubs shall have waste 
$\ominus$

$\theta$ 


\section{GLOSSARY}

Active Solar Energy System - An assembly of collectors, thermal storage device(s) and transfer liquid which converts solar energy into thermal energy and in which energy in addition to solar is used to accomplish the transfer of thermal energy.

\section{Auxiliary Energy Subsystem - Equipment utilizing} energy other than solar, both to supplement the output provided by the solar energy system as required by the design conditions, and to provide full energy backup requirements during periods when the solar energy system is inoperable.

\section{Collector, combined - The collector and storage are} constructed and operated such that they functionally perform as one unit and the thermal performance of the individual components cannot be meaningfully measured.

\section{Collector, component - Collector that is not structur-} ally integrated with the storage or building. The collector performance can be thermally characterized as an individual component with a moving heat transfer fluid.

Control subsystem - The assembly of devices and their electrical, pneumatic, or hydraulic auxiliaries used to regulate the process of collecting, transporting, storing, and 
utilizing energy in response to the thermal, safety, and health requirements of the building occupants.

Design Life - The period of time during which a system is expected to perform its intended function without requiring major maintenance or replacement.

Energy transport subsystem - That portion of a solar energy system which contains heat transfer fluids and transports energy throughout the system.

Heat transfer medium - A medium which is used to transport thermal energy.

\section{Passive solar energy system - An assembly of natural} and architectural components including collectors, thermal storage device(s) and transfer fluid which converts solar energy into thermal energy in a controlled manner and in which no fans or pumps are used to accomplish the transfer of thermal energy. The prime elements in a pasive solar system are usually some form of thermal capacitance and solar energy control.

Solar Absorbtance - The ratio of the amount of solar radiation absorbed by a surface to the amount of radiation incident on it (for terrestrial applications usually calculated for Air Mass 2 characteristics). 


\section{Solar Building - A building which utilizes solar} energy by means of an active or passive solar energy system.

Solar Energy - The photon energy originating from the sun's radiation primarily encountered in the wavelength region from 0.3 to 2.7 micrometers.

Solar Heating System - The complete assembly of subsystems and components necessary to convert solar energy into thermal energy for heating purposes in combination with auxiliary energy when required.

Solar Transmittance - The ratio of the radiant flux transmitted through and emerging from a body to the total flux incident on it.

Storage Subsystem - The assembly used for storing thermal energy so that it can be used when required.

Subsystem - A major, separable, functional assembly of a system such as complete collector, or storage, assembiy.

System - The complete assembly necessary to supply heat, domestic hot water, or other usable form of solar energy to a structure. 